University of Louisville

ThinkIR: The University of Louisville's Institutional Repository

Electronic Theses and Dissertations

8-2015

\title{
A day in the life : identity communication at the intersection of race, gender, and sexual orientation.
}

Mary C. Mudd

University of Louisville

Follow this and additional works at: https://ir.library.louisville.edu/etd

Part of the Feminist, Gender, and Sexuality Studies Commons, and the Race, Ethnicity and Post-

Colonial Studies Commons

\section{Recommended Citation}

Mudd, Mary C., "A day in the life : identity communication at the intersection of race, gender, and sexual orientation." (2015). Electronic Theses and Dissertations. Paper 2205.

https://doi.org/10.18297/etd/2205

This Master's Thesis is brought to you for free and open access by ThinkIR: The University of Louisville's Institutional Repository. It has been accepted for inclusion in Electronic Theses and Dissertations by an authorized administrator of ThinkIR: The University of Louisville's Institutional Repository. This title appears here courtesy of the author, who has retained all other copyrights. For more information, please contact thinkir@louisville.edu. 


\title{
A DAY IN THE LIFE: \\ IDENTITY COMMUNICATION AT THE INTERSECTION OF RACE, GENDER, AND SEXUAL ORIENTATION
}

\author{
By \\ Mary C. Mudd \\ B.A., University of Louisville, 2007

\begin{abstract}
A Thesis
Submitted to the Faculty of the

College of Arts and Sciences of the University of Louisville In Partial Fulfillment of the Requirements

For the Degree of
\end{abstract}

Master of Arts in Communication

Department of Communication

University of Louisville

Louisville, KY

August 2015 



\section{A DAY IN THE LIFE: \\ IDENTITY COMMUNICATION AT THE INTERSECTION \\ OF RACE, GENDER, AND SEXUAL ORIENTATION}

By

Mary C. Mudd

B.A., University of Louisville, 2007

A Thesis Approved on

July 27,2015

by the following Thesis Committee:

\begin{tabular}{c} 
Thesis Director \\
Dr. Kandi Walker \\
\hline Dr. Steve Sohn \\
\hline
\end{tabular}

Dr. David Owen 


\section{DEDICATION}

This thesis is dedicated to my children

Thomas Eli Mudd

and

\section{Rachel Marin Mudd}

who are the beginning and the end of every journey I take. 


\section{ACKNOWLEDGEMENTS}

In the Fall of 2012, I took a course titled Black Lesbian Lives, taught by Dr. Kaila Story. One of the readings for the course was ZAMI: A New Spelling of My Name, a "biomythography" written by Story's idol, Audre Lorde. It was that book, and Lorde's other writings, that introduced me to the lived experiences of intersectionality and how those experiences shape individual realities. My life was changed by reading that book, and this thesis is only one small piece of the evidence of that change. Before I can thank anyone else, then, I must first thank Audre Lorde, who bravely, openly, and without apology lived as a Black woman warrior poet, and by doing so inspired me to find the courage to exist just as authentically.

I would also like to thank my advisor, Dr. Kandi Walker, for her willingness to go against her grain and be the one who pushed me, creating the pressure I needed to get the job done. Thanks also go to the other members of my committee-Dr. Steve Sohn and Dr. David Owen - for their guidance, suggestions, and patience. This thesis would never have been written, however, without the support and encouragement of my family—my mother, who never stopped believing in me; my sister, who saw me as an academic long before I ever imagined the possibility; my brother, who never believed I could fail; and my children, who did without too much of my time and energy, and loved me anyway. Finally, I would like to thank my best friend, Natalie Topp, who endured my countless rambling rants and never told me to shut up. 


\author{
ABSTRACT \\ A DAY IN THE LIFE: \\ IDENTITY COMMUNICATION AT THE INTERSECTION \\ OF RACE, GENDER, AND SEXUAL ORIENTATION \\ Mary C. Mudd
}

July 27,2015

The theory of intersectionality posits that inclusion in multiple stigmatized identity groups results in intersectional rather than additive oppression, making it impossible to examine any one form of oppression in isolation. Black lesbians experience multiple forms of oppression — based on their sex, gender, race, and sexual orientation — making their experiences an ideal opportunity for analyzing the impact of intersectionality. Drawing from feminist theory and research, this thesis uses multiple Black lesbian narratives selected from two texts, interwoven with research from Black scholars, to present an innovative method of inquiry designed to uncover the intersections in their lives. The juxtaposition of the narratives against the scholarly research illuminates the interplay between the various forms of oppression they experience, and the unique and adaptive ways in which these women craft their identities and respond to their oppression. 
TABLE OF CONTENTS

PAGE

ACKNOWLEDGEMENTS _ iv

ABSTRACT

INTRODUCTION

LITERARY REVIEW

Traditional Research

Intersectionality

METHODOLOGY

Methods $\ldots \ldots \ldots$

Subject Selection

Choosing Texts

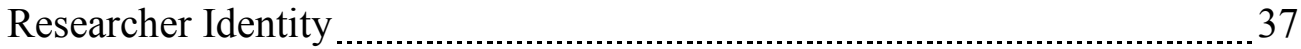

ANALYSIS $\quad 40$

CONCLUSION

REFERENCES _

CURRICULUM VITA 


\section{INTRODUCTION}

"Your silence will not protect you." - Audre Lorde

Brazilian philosopher Paulo Freire, ${ }^{1}$ who spent a large portion of his youth living in poverty, ${ }^{2}$ argued in Pedagogy of the Oppressed that the dehumanization of oppression is a vicious cycle ensnaring both the oppressed AND their oppressors. He wrote that dehumanization is "the result of an unjust order that engenders violence in the oppressors, which in turn dehumanizes the oppressed" (Freire, 1970, p. 44). Engaging in the dehumanization of others is, itself, dehumanizing. Sadly, however, while "discovering [one]self to be an oppressor may cause considerable anguish...it does not necessarily lead to solidarity with the oppressed" (Freire, 170, p. 49). Too often, the oppressors - those

\footnotetext{
${ }^{1}$ Freire was a Brazilian man whose racial identity was unclear; he married two women in his life. He held a degree (mid-40s) from Federal University of Pernambuco in Recife, Brazil, where he later attended law school.

${ }^{2}$ One of the core arguments presented in this thesis is that researcher objectivity, a central tenet of traditional academic research, is a myth that reinforces oppressive social structures; as a corrective measure, feminist scholars have called on researchers to identify their social location as a way of allowing readers to better assess the biases of the research. As such, the social locations of the researchers and writers that are cited in this thesis have been identified whenever possible. Although "the theory of intersectionality stresses complexity [...] not all categories are necessarily mentioned" (Lanehart, 2009, p. 4) so only those categories specifically related to the focus of this thesis - sex, gender, race, sexual orientation, educational background, date of degree completion, and current position, as well as any other categories that are self-reported - are noted. Information about the identities of many academics, however, is not available. The only source of information about the race or sex of a researcher, for example, may be a photograph on a university webpage; those instances are indicated by the qualifier "appears to be" (which is admittedly subjective). Additionally, when the date of a degree and/or the discipline in which it was earned are not available, that information is simply omitted. Sexual orientation is stated conclusively only when the researcher has provided that information themselves; in the absence of self-identification, marital status is noted when available. Unless it is already mentioned in the text, the identifying information is included as footnotes rather than endnotes so it can become part of the filter through which readers consider the cited information.
} 
with privilege — remain silent about the oppression they see because they fear that speaking up will jeopardize their privilege, leaving them defenseless against becoming oppressed themselves.

In December 1977, during the Lesbian and Literature panel of a meeting of the Modern Language Association, Black ${ }^{3}$ feminist lesbian, ${ }^{4}$ poet, author, and educator Audre Lorde ${ }^{5}$ gently chided women with privilege who had remained silent about forms of oppression from which they did not suffer. In her speech-“"The Transformation of Silence into Language and Action"-_Lorde called on all women to recognize that "death...is the final silence, [one which comes] quickly, now, without regard for whether [we] had ever spoken what needed to be said, or only betrayed [ourselves] into small silences" (1984, p. 41). She called on women to not simply "hide behind the mockeries of separation that have been imposed" by patriarchy, but instead to "seek out [the words of women crying to be heard], to read them and share them and examine them in their pertinence to" their own lives (Lorde, 1984, p. 43). She called on women to overcome the fear of being censured and rejected in order to speak out against not just sexism, but also

\footnotetext{
${ }^{3}$ In his article on the dangers of invisibility, Dr. David Hall argues that the word 'Black' should always be capitalized. He states that "not to do so would feed into...invisibility [because] 'Black' is more than a physical description of a person's skin color; it is a racial designation that embodies the culture, history, philosophy, and ethos of a group of people" (Hall, 2006, p. 10). While not all Black scholars agree with Hall's position, many of the women whose words I cite do capitalize the word Black. In order to be respectful of the wishes of my cited authors while also remaining consistent in my writing, I have chosen to follow Hall's lead, using [B] to indicate citations that were not capitalized in the source material.

Hall appears to be a Black man, and is married to a woman with whom he has three children. He earned multiple degrees before 1993 - both an MA in human relations and a juris doctorate (JD) from the University of Oklahoma, and both a JD and a Master of Law (LLM) from Harvard University; he currently serves as President of the University of the Virgin Islands.

${ }^{4}$ Terms used to refer to sexual orientation can be quite confusing, with little consensus on definitions. For the purposes of this thesis, I use "lesbian" to signify women who are sexually attracted to women, "gay" to refer to anyone who is sexually attracted to their own gender, "homosexual" as a clinical term for all of the above, and "queer" as a broader term that includes all of the above, as well as bisexuals and trans* people, with the caveat that there are significant race and class based differences in the common usage of all the terms.

${ }^{5}$ Lorde earned a Bachelor of Arts (BA) (1959) in library science from NY's Hunter College. She studied at the National University of Mexico for one year, and earned a Master of Arts (MA) (1961) in library sciences from Colombia University.
} 
racism, classism, homophobia, and other systems of oppression. Lorde's point was that whether those with privilege overcome the fear of being ostracized themselves in order to speak up and out for those who don't have a platform or not, they will all die; staying silent about the oppression of others will not prevent that death from coming. But in seeking out and listening to the words of other women, especially those struggling under multiple forms of oppression, all women have the power to bridge differences by rejecting the silence that builds them. Lorde urged, as did Freire, an end to the division of individual identity into discrete social categories. Categorization should be replaced with the recognition that humanity is constructed in the all the intersections of the social self. To ignore those intersections is to contribute to dehumanization, which is exactly how oppression is achieved - it divides and conquers. The separation leaves those who are simultaneously living in multiple stigmatized social worlds twisting in the wind, unable to find a safe port from which to strive for their own liberation. The results of categorization can be found by observing the aftermath of two events in 2015-the slaughter of nine African Americans ${ }^{6}$ by a White ${ }^{7}$ supremacist at a church in Charleston,

\footnotetext{
${ }^{6}$ The terms "Black", "African American", and "people of color" are used numerous times throughout this thesis and may sometimes appear to be interchangeable but are, in fact, used to denote inclusion in specific identity groups, albeit ones with permeable borders: Black refers to individuals who display phenotypical characteristics that are commonly associated with African ancestry; African American refers to only to those in the above-mentioned individuals who have spent their lives as American citizens; people of color refers to a much broader group of individuals who are considered not White and who often share similar experiences of racism.

7 As stated in an earlier footnote, I have applied to argument made by Dr. David Hall concerning capitalization of the word Black (see footnote \#3). There is no consensus among academics as to whether or not to capitalize either word, but the norm is to capitalize neither or both. In this thesis, however, I originally declined to capitalize White for two reasons. First, White people in the United States do not experience monolithic assumptions about their cultural experiences based solely on the presence of phenotypical features commonly associated with a particular ancestry, and are in no danger of becoming invisible; both of these things are experienced by Black people in the United States. Second, I felt it especially important as a White woman commenting on the lives of Black women that I offer some tangible evidence of having acknowledged and relinquished my racial privilege; declining to capitalize White was my way of doing so. In deference to the preferences of my mentors and committee, however, I have ceded the argument and have capitalized White throughout the thesis.
} 
NC and the Supreme Court ruling legalizing same-sex marriage in the United States. In the days following the massacre, Whites and Blacks were united in outrage against the racism that had reared its ugly head in Charleston. Desperately needed discussions about the reality of race relations in the United States began to emerge as White people across the country seemed ready to acknowledge the pervasive existence of racism. When the Supreme Court announced its ruling on same-sex marriage, however, discussions about oppression began shifting from racism to homophobia, rather than encompassing both. Instead of continuing the dialogue about the pervasive presence of racism in every social structure and institution, Whites (both gay and straight) settled for a token effort—the removal of Confederate flags from statehouses in the South—while people of all races zoomed in on issues of morality around gay marriage. The result was that oppressed groups were once again left squabbling with each other over the same crumbs falling off the plates of those with multiple privileges rather than demanding that the entire breadth of humanity be given a seat at the table.

Queer people of color (QPOC) were caught in the middle of the battle, faced with making a choice about whether to align with others based on race or on sexual orientation, with either option requiring them to repress some aspect of their identity. If they opted to organize with other Blacks demanding recognition of their racial identity, their sexual orientation would put them at risk of rejection by the Black community due to its strong, faith-based disapproval of homosexuality. Black pastors have been very vocal about opposition to same-sex marriage based on the belief that homosexuality is 
immoral (Dade, 2012, n.p.). ${ }^{8}$ That opposition is reflected in the position of many in the Black community; the Pew Research Center ${ }^{9}$ found that only $41 \%$ of African Americans support gay marriage (2015).

Alternately, QPOC could join White queer people in celebrating the legal recognition of their romantic relationships. That victory, however, came at the cost of focusing on issues of greater concern for QPOC. Housing and employment protections, for example, are a much more pressing needs for QPOC, for whom racism already creates discrimination in those areas. White people who are more concerned with social acceptability, however, are the ones "driving the bus" in the Gay Rights Movement; it is White gay issues and concerns that are the focus of the political efforts of many of its high-profile organizations. Numerous LGBT bloggers, for example, have criticized the Human Rights Campaign (HRC), the largest and most visible gay rights organization in the United States, for failing to allot any of the $\$ 50$ million dollars it raises annually to issues of concern to LGBT communities of color. As Huffington Post Opinion writer Derrick Clifton ${ }^{10}$ noted, "The HRC has tokenized and otherwise has given lip service to issues pertaining to LGBT communities of color. Racial justice (or even an allusion to it) isn't even listed on their website's "issues" tab as part of a broader strategy funding” (2013, n.p.). It's difficult to even find people of color on the staff or Board of HRC. The problem is highlighted in an anonymous tweet—"EQUALITY scream the

\footnotetext{
${ }^{8}$ Corey Dade appears to be an African American man. He holds a BA in journalism from the University of Maryland; he is a national correspondent for National Public Radio.

${ }^{9}$ Pew Research Center is a nonpartisan fact tank. From the pictures of board members and employees posted on their website, it appears that $100 \%$ of the Executive team is White, as are $90 \%$ of the staff; no information about their sexual orientation or other demographics was available.

${ }^{10}$ Clifton is a gay Black man. He earned a BA (2012) in communication from Northwestern, where he is currently pursuing an MA.
} 
[W] hite gays with LEGALIZE GAY across their shirts \& NO BLACKS NO ASIANS NO FEMS across their [dating] profiles".

The landscape looks even bleaker when honing in on Black lesbians. Civil rights organizations are usually headed by men, while White people are at the helm in gay rights organizations, leaving women who are Black and gay marginalized on both fronts. That compounded marginalization may explain why African American women with female partners are two times more likely than White heterosexual couples to be raising young children (Badgett, Durso, and Schneebaum, 2013, p. 2), three times more likely to live in poverty than White same-sex female couples (Badgett, Durso, and Schneebaum, 2013, p. 3), ${ }^{11}$ and earn an average of $\$ 10,000 /$ year less than Black male same-sex couples, who are themselves for behind White couples in terms of annual income (Kerby, 2013 , n.p.). ${ }^{12}$

The struggle that queer people of color face in finding a social group that celebrates all their identities illustrates the difficulties that oppressed people often face. They are complex individuals with complex experiences who occupy and personify multiple social identities simultaneously. Their experiences can only be understood by considering the ramifications of living at the intersections of those identities, because "[i]ntersectionality examines how distinctive social power relations mutually construct

\footnotetext{
${ }^{11}$ M.V. Badgett, a lesbian who appears to be White, holds a Ph.D. (1990) in economics from the University of California, Berkeley; she is currently a Professor of Economics at UCLA, where she is also a Distinguished Scholar of the Williams Institute. Laura Durso appears to be a White woman; she holds an MA and a Ph.D. from the University of Hawaii at Manoa and is currently Director of the LGBT Communications and Research Project for the Center for American Progress. Alyssa Schneebaum holds an MA (2011) and a Ph.D. (2013) from the University of Massachusetts, Amherst; no other information was available.

${ }^{12}$ Sophia Kerby appears to be a Black woman. She holds a BA in government and politics from the University of Maryland-College Park. She is a Policy Associate at the New York University School of Law's Brennan Center for Justice.
} 
each other, not just that social hierarchies exist" (Bowleg, 2008, p. 312). ${ }^{13}$ Dr. Lisa Bowleg, a self-identified Black lesbian whose research focuses on intersectionality in the lives of Black lesbians, used a single example to sum up the problem with focusing on discrete social identities rather the whole individual. As reported by her, in 1994 the National Institutes of Health called for researchers to submit plans for including "women and minorities" as if these were mutually exclusive groups. However, "[w]omen's experiences as women also intersect with their experiences as members of ethnic minority groups, as well as other historically oppressed social groups" (Bowleg, 2008, p. 313). She further noted, "Because the lives of Black lesbians are rooted in structural inequalities based on the intersections of sexual orientation, sex, gender, and race, Black lesbians are an ideal population in which to study intersectionality" (Bowleg, 2008, p. 312).

According to Freire, "[true] solidarity requires that one enter into the situation of those with whom one is solidary...the oppressor is in solidary with the oppressed only when [s] he stops regarding the oppressed as an abstract category and sees them as persons who have been unjustly dealt with" (1970, p. 49-50). In striving to achieve the true solidarity with other women, I have chosen to enter into the situation of those with whom I am solidary by studying the written works of self-identified Black lesbians discussing their experiences of marginalization. These experiences illuminate how the inseparable intersectionality of race and sexual orientation manifests itself in the lives of Black lesbians, and shapes the way their identity is communicated. I have opted to

\footnotetext{
${ }^{13}$ Bowleg earned an MA (1991) in public policy, with a concentration in Women's Studies, from George Washington University and a Ph.D. (1997) in applied social psychology from the same university; she is currently an Associate Professor of Applied Social Psychology at George Washington University's Columbian College of Arts \& Sciences.
} 
demonstrate intersectionality through their narratives both because of the experiences I share with Black lesbians and because of all the ways in which we are different.

Like the Black women whose words I have chosen to analyze, I have experienced discrimination and oppression stemming from my lesbian identity. I am interested, therefore, in examining the ways in which other lesbians negotiate the limitations imposed by hetero-normative, patriarchal society. Although my lesbian identity has exposed me to discrimination, unlike the authors of my source material, I enjoy racial privileges as a White woman. I have not experienced discrimination based on my skin color or any other phenotypical characteristics associated with racial identity. I have never had to look for positive representations of my race in the media. I have never been denied a job interview because of assumptions based on my name or my voice. As a result, I almost assuredly approach social situations differently than the Black women whose words I am analyzing.

In 1903, African American scholar W.E.B. DuBois ${ }^{14}$ coined the term "double consciousness" to describe the splintering of identity that many African Americans experienced as they attempted to navigate both Black and White social terrains (pp. 2-3). Success in social domains in which one is subordinate depend on a ability to understand the perspective of the dominant group, but there is no reciprocal obligation; the success of the dominant group requires absolutely no awareness of the struggles of subordinate members of society. Although DuBois used "double consciousness" in reference to African Americans, the term can easily be used to describe experiences of subordination

\footnotetext{
${ }^{14}$ DuBois was an African American man. He earned his first BA (1888) from the historically Black Fisk University. He then attended Harvard University, where he earned his second BA (1890) in history. As part of his a MA in sociology at Harvard, he spent a year studying at the University of Berlin. In 1895, he became the first African American to earn a Ph.D. from Harvard.
} 
in any social structure - race, gender, sexual orientation, and others. Feminist standpoint theorists, for example, borrowed the term to describe the heightened awareness women have of both their lives and the lives of the men who dominate their world (Brooks, 2005, p. 63). ${ }^{15}$ The same term could also be applied to the tension gay people feel while living in a heteronormative world. In preparation for writing this thesis, I have sought to continually analyze my own identity in order to differentiate my "double consciousness" from perspectives that have been developed through my privilege, as suggested by feminist theory.

I experience being a woman in a male-dominated world, and of being a lesbian in a heterosexist society, but I am also White. I do not have to reconcile my internal feelings about my skin color with negative societal stereotypes about it; indeed, I rarely have to think about my skin color at all. As a White woman, I cannot ignore my social position as a member of the dominant racial demographic. For me, declaring my racial privilege is an essential acknowledgement, as it is too easy for well-meaning White people to believe they are free from racial biases simply because they aren't driving around with a noose in their trunk. Nearly fifteen years of implicit association research conducted through Harvard University, however, tells a different story. The Project Implicit research, ${ }^{16}$ which measures "implicit social cognition, or thoughts and feelings outside conscious

\footnotetext{
${ }^{15}$ Abigail Brooks appears to be a White woman; she earned her Ph.D. from Boston College and is currently an Associate Professor in the Sociology Department of Providence College, where she is also the Director of the Women's Studies Program.

${ }^{16}$ Project Implicit was founded in 1998 by three scientists: Tony Greenwald, Mahzarin Banaji, and Brian Nosek. Greenwald, who appears to be a White male, received an MA (1961) and Ph.D. (1963) from Harvard University and is currently a Professor of Psychology at the University of Washington; Banaji, who was born in India and appears to be a woman of Indian descent, holds a Ph.D. (1986) from Ohio State University and is currently a Professor of Social Ethics in Harvard University's Department of Psychology; Nosek, who appears to be a White male, earned an MS (1998) in psychology, a Master of Philosophy (1999), and a Ph.D. (2002) in Psychology from Yale University. He is currently a Professor at the University of Virginia.
} 
awareness and control" (About Us, n.d., n.p.), offers significant evidence of the link between implicit attitudes and social behaviors. Project Implicit participants use a computer to complete "a flexible task designed to tap automatic associations between concepts (e.g. math and arts) and attributes (e.g. good or bad, male or female, self or other)" (Implicit Association Test, n.d., n.p.). The tests show a strong implicit association between white/good and black/bad, supporting the argument that all people have racial biases, as detailed by Anthony Greenwald and Mahzarin Banaji in the book, Blind Spot (2013).

Recognizing the existence of an implicit bias can sometimes result in racial guilt, a dangerous pitfall that can derail even the most well-intentioned efforts. White people consumed by White guilt often try to assuage their guilt by "helping" Black people. Freire dismissed the "false generosity" of the privileged, however, because it supports rather than dismantles oppression; the oppressors must defend an oppressive social hierarchy because the hierarchy is what gives them the greater status and power from which they generate the excess resources they so "generously" offer (1970, p. 44). In writing this thesis, I am attempting to contribute to the dismantling of the social hierarchy that provides me with racial privilege by adding to the body of literature urging researchers to stop trying to dissect the singular social identities of individuals. Limiting the study of social identity to disconnected social parts will never reveal any useful knowledge about individuals because identity lies in the intersections and the complex interplay between social identities_-knowledge that can only be obtained by validating and valuing the intersectional experiences of others. 
It is essential to note that I am analyzing the words of Black lesbians as an outsider. No amount of time spent in Black communities or reading the words of Black women, no amount of distancing myself from the White privilege that was handed to me at birth, will change the reality that I cannot know what it feels like to walk around in Black skin. As a White woman writing about the experiences that helped to shape the social identities of Black lesbians, therefore, I am speaking for others. In her essay, titled "The Problem of Speaking for Others", Linda Alcoff ${ }^{17}$ argued that when those with privilege speak up for those who are oppressed, they run the risk of becoming the accepted authority on the lives of the people for whom they are speaking up (1991, p. 1718). Like Audre Lorde, however, Alcoff cautioned against simply deciding not to speak for others at all, noting that "a complete retreat from speech is...not neutral since it allows the continued dominance of current discourses and acts of by omission" (1991, p. 13). She instead offers some guidelines for how to avoid the pitfalls of speaking from a dominant position about the experiences of those who are subordinate (Alcoff, 1991, pp 17-19). The guidelines include critiquing the motivation to speak to ensure that it stems from a desire to advance the message of the subordinate group rather than to demonstrate self-knowledge; an honest evaluation and acknowledgement of one's own social location; an openness to accepting criticism, particularly from the subordinate group; and an analysis of "where the speech goes and what it does there" (Alcoff, 1991, p. 19) in order to be accountable for the impact of one's words.

As suggested by Alcoff, I have attempted to reflexively and critically analyze my own standpoint and life experiences enough to understand how they shape my approach

\footnotetext{
${ }^{17}$ Alcoff is Panamanian and identifies as having a mixed racial identity. She holds an MA in philosophy from Georgia State University and a Ph.D. (1987) from Brown University. She is currently a Professor of Philosophy at Hunter College, Audre Lorde's alma mater.
} 
to my research. I have attempted to interrogate my own position and how it affects my conclusions in order to be accountable for my words and their consequences. Even if I have failed, though, I cannot refuse to reflect on the words of women of color simply because I might understand them incorrectly. As Lorde said in 1977, "It is not our differences which immobilizes us, but silence" (1984, p. 44). Even a misunderstanding can begin an authentic dialogue through which to begin understanding the intersectional experiences and identities of others. My thesis is an effort to initiate that dialogue by offering the words of women crying out to be heard, and by using the insights of similarly socially situated theorists to extrapolate meaning from the words. In this way, I hope to contribute to the generation of knowledge for marginalized people, which is a fundamental starting point for overthrowing the yoke of oppression for all. 


\section{LITERATURE REVIEW}

"There is no such thing as a single-issue struggle because we do not live single-issue lives." - Audre Lorde

Academic research is an invaluable tool used by politicians to craft and enact public policies. Too often, however, politicians attempt to address the inequalities experiences by marginalized communities based on the values and desired outcomes of a “[W]hite supremacist capitalist patriarchy” (hooks, 2004, p. 17), ${ }^{18}$ which is supported by positivist research that views individuals "in isolation from and unconnected with [their] interpersonal, historical, or physical context" (Sprague, 2005, p. 16.). ${ }^{19}$ Such research disregards the compounded inequality that stems from intersecting forms of oppression. The failure to acknowledge these intersections is why it is a mistake for those who enjoy a privileged social location to presume to know what marginalized individuals and communities want and need; too many important aspects of the identities of the marginalized are ignored.

Traditionally, research has reduced the oppressed to objects devoid of agency in their own lives, making it easy to cast them as inferior, incapable of possessing their own

\footnotetext{
${ }^{18}$ bell hooks [sic] is an African American woman who rejects the label of "heterosexual" because of its implied suggestion that a woman's body is open and available to men. She holds an MA (1976) in English from the University of Wisconsin-Madison and a Ph.D. in literature from the University of California, Santa Cruz. She is currently a Distinguished Professor in Residence in Appalachian Studies at Berea College.

${ }^{19}$ Sprague identifies herself as a White, heterosexual mother and tenured Professor of Sociology with a working class background; she earned an MA (1978) in sociology from the University of WisconsinMilwaukee and a Ph.D. (1986) in sociology from the University of Wisconsin-Madison; she is currently a Sociology Professor at the University of Kansas.
} 
knowledge, and unable to determine what is in their own best interests. Rather than listen to the voices of the oppressed, then, politicians simply craft solutions using the conclusions of research that has "stud[ied] down' [by] direct[ing...] attention to those who have less power" (Sprague, 2005, p. 11). Research done from this perspective presumes that it is the lack of power, rather than the wielding of it, that is the problem. That presumption flies in the face of feminist epistemology rooted in standpoint theory, which produces knowledge "for marginalized groups, rather than about marginalized groups for the use of dominant groups to maintain hierarchical power relations" (HesseBiber, Leavy, \& Yaiser, 2004, p. 16). ${ }^{20}$

\section{$\underline{\text { Traditional Research }}$}

Social science research in the academy has historically been androcentric, or "produced in male-dominated spheres" (Hesse-Biber \& Yaiser, 2004, p. 6). Men were placed at the forefront of every study, with the assumption that what was true of men would also be true of women. Even if some researchers recognized that the experiences of women differed from those of men, the experiences of men were still considered normative. Some might argue that such a myopic lens is no longer the norm, but the academy certainly still fits the description of a male-dominated sphere. According to the National Center for Education Statistics, ${ }^{21}$ as of $2011,60 \%$ of full-time university professors were White men (2014, n.p.). The argument that bias is imbedded in

\footnotetext{
${ }^{20}$ Sharlene Hesse-Biber appears to be a White woman; she earned all her degrees-BA, MA, and Ph.D.in sociology at the University of Michigan, Ann Arbor. Patricia Leavy, who appears to be a White woman, earned a Ph.D. (2002) in sociology from Boston College and currently works as an independent researcher. The most recent data available for Michelle Yaiser indicates that she received a Ph.D. in Sociology in or around 2001; no other information about her could be located.

${ }^{21}$ The National Center for Education Statistics, housed in the US Department of Education, is the congressionally mandated primary entity for collecting and analyzing education related data in the United States; no statistics on the demographic breakdown of the center's staff was available.
} 
traditional research processes is echoed in the criticisms articulated for years by researchers in Women's and Gender Studies, Queer Studies, and Black Studies. Each of these disciplines holds that a fundamental flaw of traditional academic research is the assumption that all 'normal' behavior exists within a paradigm shaped by the dominant culture (e.g. male, heterosexual, White). Any behavior that falls outside that paradigm is viewed as an anomaly to be studied in order to arrive at generalized understandings about how those outside the dominant paradigm operate.

Sprague argued, however, that "understanding how things work is not enoughwe need to take action to make the social world a more equitable place" $(2005$, p. 3$)$. Solutions that are based on the perspectives of those with privilege and power, however, will do little to alleviate the marginalization of those who have neither, unless the solutions stem from their perspectives. The emergence of disciplines like Women's and Gender Studies, Queer Studies, and Black Studies is encouraging. It has certainly led to academic research that considers identity elements which have been rendered mute or invisible by androcentric research. As these disciplines have gained status and respect, the research generated by its scholars has been used to support a variety of policies intended to assist oppressed communities. Despite some positive contributions, however, these disciplines are still problematic. First, like the androcentric and ethnocentric scholarship they attempt to disrupt, scholars from these disciplines also attempt to isolate discrete identity elements, albeit ones that have traditionally been overlooked. Isolating identity elements ignores the interplay between the multiple identities held by all. As a result, even as one identity element is brought into the spotlight, other elements are once again rendered invisible. In the introduction to the anthology All The Women Are White, 
All The Blacks Are Men, But Some of Us Are Brave: Black Women's Studies, Gloria T.

Hull and Barbara Smith, both former members of the Combahee River Collective, a

feminist group active in Boston in the late 70s and comprised of women of color who

focused on the intersections of oppression in the lives of women, noted:

Women's studies courses, usually taught in universities, which could be considered elite institutions just by virtue of the populations they served, focused almost exclusively upon the lives of [W] hite women. Black studies, which was much too often male-dominated, also ignored Black women (Hull \& Smith, 1982, p. xx). ${ }^{22}$

Second, these scholars often conduct research using the same quantitative and qualitative methods and models used by traditional researchers, methods that aren't practical when attempting to understand the lived experiences of people burdened by multiple stigmatized identities. At best, they often take an "additive" approach, which "posits that social inequality increases with each additional stigmatized identity" (Bowleg, 2008, pg. 314). Identity and individual experiences, however, cannot be carved up into separate pieces; they are an inseparable whole.

Intersectionality

“Ain’t I a woman?” Abolitionist, suffragist, and former slave Sojourner Truth ${ }^{23}$ never uttered these exact words when she spoke at the Akron, Ohio Women's Convention in $1851,{ }^{24}$ but the question was in the speech she delivered just the same. When Truth

\footnotetext{
${ }^{22}$ Hull is an African-American woman who earned her Ph.D. (1972) in English literature from Purdue University. Smith, an African-American lesbian, holds an MA in Literature from the University of Pittsburgh and was nominated for a Nobel Peace Prize in 2005.

${ }^{23}$ Truth was an African American woman born into slavery in the early 1800s.

${ }^{24}$ According to researcher Corona Brezina (for whom no demographic information was available), Truth's original speech was not transcribed. Marius Robinson, an abolitionist who was present in the audience, worked with Truth a month after she delivered the speech to develop a fairly accurate depiction of the speech's content. The historically accepted version, offered twelve years after the convention by White suffragist Frances Gage, included the question “Ain't I a woman?” repeated four times. Gage's version,
} 
bared her muscular forearm and recalled the many fields she had plowed, she was seeking to shatter notions of women as frail, dainty, White society ladies who needed to be helped into carriages and down stairs. Lest anyone have any doubt as to her sex, she went on to speak of the children she had borne and the tears she had shed for their plight. Truth's speech challenged the almost exclusively White audience to acknowledge her identity as a woman, an identity that historically had been negated by the color of her skin.

Over 100 years later, legal scholar Kimberle Crenshaw ${ }^{25}$ coined the term “intersectionality" to explain Truth's simultaneous experiences of race and gender. As explained by Crenshaw, intersectionality is a concept of identity which focuses on how multiple systems of oppression and discrimination (e.g. racism, sexism, classism, heteronormativity) intersect in and shape the lives of marginalized or disenfranchised people. Crenshaw noted that many oppressed individuals—women, people of color, gays and lesbians - have come to "recognize that the political demands of millions speak more powerfully than the pleas of a few isolated voices" (1991, p. 1241). These oppressed individuals have banded together with others who have experienced comparably based oppression to form political identity groups. While these groups can be "a source of strength, community, and intellectual development" (Crenshaw, 1991, p. 1242), they can also be guilty of disregarding the intersections of oppression experienced by individual members. As she noted:

\footnotetext{
however, contains multiple inaccuracies, including indications that Truth's speech featured Southern vernacular; Truth was born and raised in New York, and only spoke Dutch until she was nine, so it is unlikely that she used Southern syntax (Brezina, 2005, p. 30).

${ }^{25}$ Crenshaw is an African-American woman and a Professor at the UCLA School of Law and Columbia Law School; she has a BA from Cornell (1981), a JD from Harvard (1984), and an LLM (1985) from the University of Wisconsin. Her sexual orientation is unknown.
} 
Feminist efforts to politicize experiences of women and antiracist efforts to politicize experiences of people of color have frequently proceeded as though the issues and experiences they each detail occur on mutually exclusive terrains. Although racism and sexism readily intersect in the lives of real people, they seldom do in feminist and antiracist practices. (Crenshaw, 1991, p. 1242)

Crenshaw's essay focused on female victims of domestic violence, and the policies that have been designed to help them. She found that such policies often fail to consider the ways in which other identity elements impact abused women. For example, one researcher stated that White women were probably absent from samples taken at battered women's shelters, which serve low income women, because White women have access to greater resources. Those same White women, however, are often financially dependent on husbands who control the household assets. Thus, shelters with policies that require poverty as a condition of assistance ignore the ways in which class, race, and gender intersect in the lives of these women.

Critical theorist Patricia Hill Collins ${ }^{26}$ has expanded the available scholarship on intersectionality. Collins specifically focuses on the lives of Black women, both heterosexual and homosexual, with a particular emphasis on how assumptions about their sexuality have been used to justify their oppression. In Black Feminist Thought, she noted that "because race has been constructed as a biological category that is rooted in the body, controlling Black sexuality has long been important in preserving racial boundaries" (Collins, 2000, p. 144). According to Collins, sexuality is divided into two categories - normal or deviant. Heterosexuality is normalized while deviant sexuality is defined as either hypersexual or homosexual. Further, Collins argued that "within assumptions of normalized heterosexuality, regardless of individual behavior, being

\footnotetext{
${ }^{26}$ Collins is an African American woman married to a man. She holds an MA (1970) from Harvard University in teaching in social science and a Ph.D. (1984) in sociology from Brandeis University. She is currently a Distinguished Professor of Sociology at the University of Maryland.
} 
White marks the normal category of heterosexuality. In contrast, being Black signals the wild, out-of-control hypersexuality of excessive sexual appetite" (Collins, 2000, p. 140), a stereotype that grew out of slavery.

In order to justify the introduction of chattel slavery in the 1600s, White Europeans created and disseminated hypersexualized stereotypes of African Americans. The brutal conditions in which Black males slaves were forced to work was justified as being necessary to tame a deviant sexuality which, if left unchecked, would result in the rape of White women. The deviance of Black men was then blamed on Black women. In Black Sexual Politics, Collins explained that “[B]lack women's bodies [were depicted] as the sites of wild, unrestrained sexuality that could be tamed but never completely subdued" (2005, p. 56), with Black women constructed as "unnatural, dirty, sick, and sinful" (Collins, 2000, p. 139). Black men were believed to be sexually deviant "because of the lascivious character of the women of the race in a time when women were considered the foundation of a group's morality" (Giddings, 1992, p. 443). ${ }^{27}$ This hypersexuality was then juxtaposed against the purity of White Womanhood, casting Black women as the "sexual, immoral counterparts" to "asexual, moral women to be protected by marriage" (Collins, 2000, p. 144 ). All Black female bodies, therefore, were considered sexually deviant. Homosexuality in women, on the other hand, was seen as deviant because of an assumed lack of sexual desire, an unacceptable position for a woman in a patriarchal system (Collins, 2000, p. 140). Black lesbians, therefore, were doubly deviant by White standards - first simply by nature of their skin color, and second

\footnotetext{
${ }^{27}$ Paula Giddings is an African American woman. She earned a BA (1969) from Howard University. Although she never earned an advanced degree, Giddings has taught as a Visiting professor at Princeton and Duke Universities, among others.
} 
because they failed to display acceptable desire for men. Their compounded perceived deviance made it easier to support and justify their demonization and subjugation.

Research that attempts to isolate gender while ignoring race and sexual orientation, therefore, will fail to discern the specific ways in systems of oppression intersect in the lives of Black lesbians. According to co-cultural theory, developed by Mark Orbe ${ }^{28}$ members of marginalized groups strategically use communication to coordinate responds to oppression (Littlejohn \& Foss, 2011, p. 217). ${ }^{29}$ The theory identifies twenty-six co-cultural practices used by group members. The particular practice selected at any given time is influenced by several factors, including field of experience, situational context, individual abilities, and perceived costs and rewards (Orbe \& Spellers, 2005, p. 178) ${ }^{30}$. Standpoint theory also explores "group standpoints, [which] are situated in, reflect, and help shape unjust power relations" (Collins, 2000, p. 28). While Collins agrees that members of marginalized groups are often subjected to similar forms of oppression, she rejects the idea that all members of a marginalized group collectively develop strategic responses to the oppression, in part due to intersecting identities (Collins, 2000, p. 30). "A feminist theoretical lens [that pays] particular attention to the interplays between gender and other forms of power and difference" (Buch \& Staller, 2007, p. 190), ${ }^{31}$ therefore, is more likely to uncover the impact of intersectionality, and

\footnotetext{
${ }^{28}$ Orbe appears to be White male; he earned his MA (1989) in higher education administration from the University of Connecticut, and a Ph.D. (1993) in interpersonal/intercultural commination from Ohio State University.

${ }^{29}$ Stephen Littlejohn appears to be a White male; he holds a Ph.D. (1970) from the University of Utah. Karen Foss also appears to be a White woman; she earned her Ph.D. (1976) at the University of Iowa.

${ }^{30}$ Regina Spellers Sims appears to be an African American woman; she earned an MBA from the University of Bridgeport and a Ph.D. in intercultural and organizational communication from Arizona State University. She is currently the Associate Director of DePaul University's DePaul Christian Ministries program.

${ }^{31}$ Elana Buch appears to be a White woman; she earned two degrees from the University of Michigan — an MA (2005) in sociological anthropology and a joint doctorate (2010) in social work and social science,
} 
how Black lesbians respond to the oppression they experience as members of multiple stigmatized groups.

It can be difficult to locate intersectional research, in part because there is a lack of understanding among academics about exactly what it is or how it should be used in their research (Davis, 2008, p. 67). ${ }^{32}$ The lack of understanding may explain why the theory simply isn't present in many academic disciplines. As Lisa Bowleg noted, "[d]espite an abundance of theories on social identity within psychology, the prevailing view of social identities is one of uni-dimensionality and independence, rather than intersection" (2008, p. 313). She also found that the term "intersectionality" is rarely used, even by feminist researchers who recognize intersectional oppression. The absence may be due to the unique challenges that intersectional research poses. Too often, research efforts adopt an additive approach, which "critics reject... because it conceptualizes people's experiences as separate, independent, and summative [implying that] one's identities and/or discrimination based on those identities can be ranked" (Bowleg, 2008, p. 314).

Bowleg argued that "it is virtually impossible, particularly in quantitative research, to ask questions about intersectionality that are not inherently additive" (Bowleg, 2008, p. 314). She found that questions which elicited narrative responses were most likely to capture experiences of intersectionality (Bowleg, 2008, p. 315). However, extracting intersectional knowledge about large groups from narratives can be

anthropology and social work. Karen Staller appears to be a White woman. She earned a JD (1985) from Cornell and an M.Phil. (1995) and Ph.D. (1999) in social policy from Columbia University. She is currently an Associate Professor of Social Work at the University of Michigan.

${ }^{32}$ Kathy Davis appears to be a White woman. She is holds the position of senior researcher at the Institute of History and Culture at Utrecht University in the Netherlands; no information about her educational background was available. 
challenging due to the traditional approach of considering narratives as individual accounts rather than as part of historic social structures. On the surface, the narratives of Black lesbians, for example, may seem to "mirror the multiple role stress narratives of many...women" (Bowleg, 2008, p. 318). In order to fully understand the impact of intersectionality, researchers must acquaint themselves with the "sociohistorical realities of historically oppressed groups, $[\ldots]$ forgo disciplinary myopia and seek out knowledge about participants' experiences employing the insights of other fields of study" (Bowleg, 2008, p. 318).

My thesis attempts to address some of the methodological challenges of intersectionality research by first critiquing what constitutes an acceptable methodology. I have then attempted to construct an alternate methodology that allows Black lesbians to speak for themselves without guiding them to discuss that which I wish to hear. By using the new methodology, I hope to avoid generating research simply to demonstrate my own knowledge, opting instead to allow Black lesbians to show the world what they know. 


\section{METHODOLOGY}

“The master's house will never be dismantled using the master's tools." - Audre Lorde

In a speech for the New York University Institute for the Humanities conference, Audre Lorde noted that only two Black women had been invited to speak at the conference, and then only on the topic of being Black. The relegation of Black women to only racial topics angered Lorde, who felt offended at the implication that Black women had nothing to say about sexism, classism, power dynamics, or any other topic being discussed at the conference. She accused White women of replicating the racist attitudes toward Black women that were held by White men, arguing that only "the most narrow parameters of change" (Lorde, 1984, p. 110) can be achieved when examining power dynamics using methods of inquiry shaped by the perspective of those who hold the power. Lorde's argument was that social science methodology has been built using the tools of patriarchy, so any social science research that strives toward dismantling oppression and dehumanization must begin with the construction of new methodological tools, ones that can uncover intersectionality in the construction of identity.

The first step to creating a new methodology is to identify the problems with the old methodology. In the opening chapter of Feminist Methodologies for Critical Researchers, Sprague unequivocally stated that, "all knowledge develops out of specific social contexts and sets of politically relevant interests, and...mainstream social science $[\ldots]$ tends to assume the position of privileged groups, helping to naturalize and sustain 
their privilege in the process" $(2005$, p. 2$)$. Hesse-Biber and Leavy found that traditional social science research reaffirmed the privilege of dominant groups in part by assuming that the researcher - the knower - could be objective, and that what could be known could be discovered through value-free methods of observation (2007, p. 6). Androcentric research was modeled on the assumption that observations could indeed be value-free and that researchers ccould be objective. Yet such research always placed men at the forefront of the study. Women were consistently placed in the role of the "other," resulting in “scientific oppression" (Halpin, as quoted by Hesse-Biber \& Yaiser, 2004, p. 12) ${ }^{33}$ which rendered them invisible through the systemic act of neglecting to address their questions about the world around them (Hall, 2006, p. 11).

Feminist research emerged out of a desire to challenge the assumption that women were non-normative. Despite efforts to dismantle the male privilege inherent in androcentric research, however, early feminist research replicated many androcentric epistemological assumptions about what can be known. Just as androcentric research assumed that women could be known and understood by studying men, early feminist research assumed that women of color or queer women could be known and understood by studying White women or heterosexual women. As Hesse-Biber and Yaiser explain, early feminist studies:

...often ignored differences among women in terms of race, class, ethnicity, sexuality, and nationality. These studies often "added women and stirred" to preexisting methodological and epistemological frameworks. Within contemporary feminist research, there has been a growing recognition of the problematic concept of a universalized "woman" or "women" (2004, p. 4).

\footnotetext{
${ }^{33}$ Zuleyma Tang-Martinez (nee Halpin) was born in Venezuela and identifies as a lesbian. She earned an MA (1970) and Ph.D. (1975) in zoology from UC Berkeley and retired as a Professor of Biology at the University of Missouri-Kansas City in 2011.
} 
Early feminist studies failed to address the concerns of queer women and women of color because they were using a primary tool of social science patriarchy to study the lives of women - positivism, which Sprague finds has "dominated scientific discourse so completely that its specific way of connecting beliefs about knowing with research practices appears seamless" $(2005$, p. 4). The myth of objectivity is a central tenet of positivism, "an epistemology of the fact," which holds that “...subjectivity is an obstacle to knowledge; the observer's personality and feelings introduce errors in judgment" (Sprague, 2005, p. 32). Like androcentric researchers, early feminist researchers took a positivist approach to research, assuming that they could separate their research from their own identity, belief system, and worldview in order to objectively "access social reality" (Hesse-Biber \& Yaiser, 2004, p. 17). The researcher, however, cannot be separated from the research. Every aspect of research—“" $[\mathrm{t}]$ he questions asked, the variables and their conceptualizations, the design of the research project, and the judgment criteria used" (Hesse-Biber \& Yaiser, 2004, p. 14)—is shaped by the perspective of the researcher, leading later feminist researchers to develop concerns about how a researcher's personal characteristics can and do affect the research project (HesseBiber \& Yaiser, 2004, p. 4).

Contemporary feminist theorists acknowledge that a researcher's observations are invariably biased by their personal identity, arguing that researchers should attach themselves to the research process in order to reduce the invisibility of their biases. When all parties involved in research are visible, hierarchy is reduced, allowing researchers and subjects to become co-collaborators in the process of creating knowledge. Sandra 
Harding $^{34}$, Distinguished Professor of Education and Gender Studies at the University of California Los Angeles, recommended that researchers also disclose why they chose to study a topic, and the process they used for deciding how to study it. She argued that "acknowledging the fact that objectivity is limited to the researcher's situation and is absent from the context of discovery actually strengthens objectivity" (Hesse-Biber \& Yaiser, 2004, p. 13) because it results in a better understanding of the issues inherent in the topic. Sprague echoed the sentiments of Harding, finding that "knowledge is socially and historically grounded" (2005, p. 3). She acknowledged her identity as a White, heterosexual, female professor with tenure in order to shed light on the ways that her social location may make her more open to some conclusions while blinding her to others (Sprague, 2005, p. 3). ${ }^{35}$

The shift away from positivist research and toward a research framework that can access what Michel Foucault ${ }^{36}$ called "subjugated knowledges" (1997, p. 7), however, requires more than just acknowledging the bias of the researcher. It also requires a rejection of the tools of positivist research. The methodologies on which positivist research is built must be dismantled because "the relationship between epistemology and methods is a direct one" (Hesse-Biber \& Yaiser, 2004, p. 6). Feminist researcher Nancy Naples ${ }^{37}$ argued that research can expose and challenge existing frameworks through the creation of new methodological strategies that strive to "seriously and self-reflexively

\footnotetext{
${ }^{34}$ Harding appears to be White; her sexual orientation is unconfirmed. She earned a Ph.D. (1973) in philosophy from New York College.

${ }^{35}$ The belief that a researcher should reveal their social location is by no means universal among critical theorists. Many of the researchers cited for this thesis do not identify their social location in their texts, nor is the information publicly available.

${ }^{36}$ Foucault was a White, gay man from an upper-class French family. He was awarded a Ph.D. (1961) in the philosophy of psychology from the École Normale Supérieure, a prestigious private university.

${ }^{37}$ Naples, a White woman, is a Professor of Sociology and Women's Studies at the University of Connecticut who has taught numerous courses on LGBT issues. She earned a Master of Social Work (1979) from CUNY Hunter College and a Ph.D. (1988) in sociology from CUNY.
} 
'deconstruct' our practices so that we can 'reconstruct' them with fewer negative consequences" (Naples, 2003, p. 37). Leckenby ${ }^{38}$ and Hesse-Biber found that research which seeks to uncover subjugated knowledges requires a broader collection of methods than that which has been developed by positivist research (2007, p. 209). The toolbox of an intersectional researcher synergizes epistemology, methodology, and method to "interrogate the status quo [...and] to raise consciousness about how we do research" (Leckenby \& Hesse-Biber, 2007, p. 210). This synergy requires researchers to continually interrogate their own location by engaging their identity and role as both researcher and participant in knowledge construction (Leckenby \& Hesse-Biber, 2007, p. 211).

These feminist researchers are arguing that many current social science theories have been built using the tools, or methods, of traditional research. It can be predicted, therefore, that these theories will fall short in attempting to explain the constraints on identity communication experienced by individuals with multiple intersecting identities that are stigmatized in larger social systems. Susan Geiger, ${ }^{39}$ a White lesbian who was Associate Professor of Women's Studies and the Center for Advanced Feminist Studies at the University of Minnesota, suggested "feminist methodology" as a remedy, arguing that it can:

Serve as a corrective for androcentric notions and assumptions about what is "normal" by establishing or contributing to a new knowledge base for understanding women's lives and the gendered elements of the broader social world [by accepting] women's own interpretations of their identities, their experiences, and social worlds as containing and reflecting important truths (2004, p. 400).

\footnotetext{
${ }^{38}$ No demographic data on Denise Leckenby, who is or was a Teaching Fellow at Boston College, was available.

${ }^{39}$ Geiger received her Ph.D. (1973) in African history from the University of Dar es Salaam (Tanzania).
} 
One methodological approach, advocated by sociology professor Leslie McCall $(2001),{ }^{40}$ is anti-categorical. As explained by Winker and Degele, ${ }^{41}$ the anti-categorical approach deals "not with empirical research [but...] with the implicit assumptions that lie behind every research method. The analysis of identity construction is primarily conducted on the micro level; the analysis of the structural positioning of large groups is...grounded in the macro level" (2011, p. 53). Anti-categorical research is less concerned with results that can be generalized to broader populations than it is with addressing "issues of difference, the questioning of social power, [and] resistance to scientific oppression" (Hesse-Biber \& Yaiser, 2004, p. 3). Where traditional social science research often attempts to quantify lived experiences, for example, by counting the number of times a subject uses predetermined buzzwords or refers to an established list of topics, feminist research makes the experience itself an important category of research, similar to the micro level of an anti-categorical approach.

The anti-categorical approach is exactly what Bowleg was suggesting when she argued that researchers must acquaint themselves with the "sociohistorical realities of historically oppressed groups" (Bowleg, 2008, p. 318) in order to unearth intersections of identity. This thesis will attempt to expose those intersections by using an anti-categorical approach that draws from theories of feminist research to operate at both the micro and macro level. The micro level data will be engaged through excerpts from the published

\footnotetext{
${ }^{40}$ McCall appears to be a White woman; she earned an MA (1990) and a Ph.D. (1995) in sociology from the University of Wisconsin-Madison. She is currently a sociology professor at Northwestern University.

${ }^{41}$ Gabriele Winker appears to be a White woman; she earned a doctorate (1994) from Germany's University of Bremen. She is currently a Professor of Human Factors and Gender Studies at the Technical University Hamburg. Nina Degele is a lesbian who appears to be White. She holds a doctorate (1993) from the University of Munich. She is currently a sociology professor at Germany's University of Freiburg.
} 
works of self-identified Black lesbians. Those narratives will be juxtaposed against the macro-level analysis of social structures that have been published by Black theorists.

\section{$\underline{\text { Methods }}$}

In this thesis, feminist standpoint theory serves as the starting point for determining a method of analyzing the narratives of lesbians in order to bring to light the ways in which the intersections of marginalization shape their identities and how they disclose those identities. In a 2013 interview for Ms. Magazine, Sandra Harding explains:

Standpoint theory is a theory of knowledge, but in most disciplines it is regarded as a methodology, a way to do research. Standpoint approaches use the differences between a dominant group's values and interests and those of subordinate groups to provide research that is for the subordinate group - that answers the kinds of questions they want answered. $(2013$, n.p.)

Standpoint theory is useful in explaining how social science research reaffirms privilege. For those individuals holding subordinate positions within a society, understanding how to communicate with those in dominant positions is essential for survival. One cannot get a job, obtain housing, avoid persecution, or accomplish any host of other tasks of living without the acceptance, however tenuous it may be, of those in power. That acceptance is easier to gain if the perspective of those in power is understood. Those with the power, however, have no burden to understand the perspectives of those subordinate to them.

As explained by standpoint theory, the power dynamic at play between socially marginalized individuals and privileged academic researchers make it difficult to conduct qualitative research on the role of intersectionality, particularly as it plays out in the lives of marginalized people, like Black lesbians, who prefer to remain hidden. One way social scientists have attempted to study marginalized populations is through interviews, which 
are then coded and quantified to arrive at generalizable conclusions. Interviewing Black lesbians about their lives, however, will fail to "convey situated experiential realities in terms that are locally comprehensible" (Rubin and Rubin, 1995, p. 9). ${ }^{42}$ Interviewing subjects will fail because it reaffirms "positivism's ontological tenet that there is some single fixed reality about intersectionality that can be measured if only the researcher has asked just the right question [...but...] there is no single reality about the experience of one's intersecting identities, only multiple constructed realities about one's own experiences" (Bowleg, 2008, p. 317). Interviewing subjects to extract generalizable data would encourage a "vessel-of-answers view" that treats Black lesbians as if they are "repositories of facts and the related details of experience" (Rubin and Rubin, 1995, p. 8) rather than as holders of unique knowledge accumulated over a lifetime.

By choosing to use Black lesbian narratives written with minimal external prompting and no interaction with me, however, I have removed the interviewer from the equation, thus reducing the power dynamics at play. The Black lesbians I am citing have chosen for themselves what topics to discuss, at what depth, and in what manner. The narratives are sometimes messy and rambling, ranging from passionate poetry to detached discussion. They sometimes cover many years in a woman's life and other times mere moments. All the narratives, however, deal with life as a Black lesbian and reflect both identity facets externally on display and the internal processing of individual experiences.

As has already been stated, being Black and female and gay is a holistic experience that cannot be separated; these women are all of these things in every moment

\footnotetext{
${ }^{42}$ The last available data about Herbert and Irene Rubin, a married heterosexual couple who appear to be White, is that both hold positions as Professors Emeritus at Northern Illinois University (he in sociology and she in public administration); no other information about them was available.
} 
of their lives. I cannot hope to examine every intersectional experience my narrators have, nor is it necessary to do so (Lanehart, 2009, p. 1) ${ }^{43}$ so I have decided to focus on those identity elements that the authors themselves have chosen to highlight. In the first two pages of Zami, Audre Lorde indicates her focus by offering a series of brief vignettes about being Black, female, and gay, and the contributors to Does Your Mama Know? were specifically chosen because they were Black, female, and gay. I have, therefore, limited my consideration to the sex, gender, race, and sexual orientation of my narrators, choosing excerpts that specifically address their intersectionality with regard to those identities. In the excerpts I have chosen, the women discuss interactions with White women, Black men, and heterosexuals or homosexuals of any hue, and how their Black lesbian identity created clashes in those interactions. The interactions are then interspliced with research from Black theorists to explain the larger social structures surrounding the experiences in order to provide a sociohistoric context.

What I have described thus far sounds a lot like textual or content analysis. The textual analysis of traditional social science research, however, requires the creation of a coding system, one which quantifies the number of times a particular word or sentence structure is used, for example, or how often a particular topic is mentioned. I have chosen not to code or quantify the texts I am using. Certainly, without quantifying the texts, the resulting analysis of excerpts is subjective, but that is the point of feminist critiques-all research is subjective. I am simply acknowledging my subjectivity at the onset, rather than attempting to pretend that I am objective.

\footnotetext{
${ }^{43}$ Sonja Lanehart appears to be an African American woman. She holds both an MA (1991) and a Ph.D. (1995) in English language and literature from the University of Michigan. She is currently the Brackenridge Endowed Chair in Literature and the Humanities at the University of Texas at San Antonio.
} 
Further, no knowledge about the real lives of Black lesbians can be gained from turning their life experiences into numbers on a graph. The real understanding comes from acknowledging and attempting to understand the intersectionality of the social identities that shape individual narratives of Black lesbians. Dr. David Boje ${ }^{44}$ found that, "Every story legitimates a centred [sic] point of view, a worldview, or an ideology among alternatives. [...] Story is never alone; it lives and breathes its meaning in a web of other stories" (2001, p. 18). Boje, who is primarily concerned with corporate narratives, engages in what he terms "story deconstruction analysis," which emphasizes a reinterpretation of the hierarchy that shapes a narrative in order to give voice to the views of those in the subordinate position (2001, p. 21). In my thesis, the reinterpretation of hierarchy is achieved by contextualizing the narratives through an analysis of social structures offered by Black scholars.

My analysis strives to give a voice to subjugated women by legitimizing the narratives of identity and oppression offered by Black lesbians who have been further marginalized within or outside the lesbian social strata by their racial identity. Multiple narratives recounting experiences of racial oppression will not be required in order to acknowledge the existence of racial oppression within the lesbian community; each individual experience will be accepted as accurate. Whenever possible, an analysis of those experiences will use the lens of various Black theorists and writers. The use of Black scholars is done for several reasons. First, it will increase the likelihood that I am offering a culturally relative rather than ethnocentric interpretation of the experiences of women-Black lesbians — who belong to a different racial group than do I. Second, it

\footnotetext{
${ }^{44}$ Boje appears to be a White male Professor. He is the Bill Daniels Ethics Fellow at New Mexico State University, and was awarded an honorary doctorate (2011) from Denmark's Aalborg University.
} 
will ensure that I am generating knowledge for marginalized women, not about them. Third, it will force me to continually critique my own privilege.

\section{$\underline{\text { Subject Selection }}$}

I have chosen to focus on Black lesbians for two reasons. First, I am a lesbian, which perhaps gives me a greater insight into the experiences of lesbians. At the very least, it explains my interest in this particular group. Second, lesbians provide an excellent sample of limitless cultural groups and ideologies in the United States. Anthropological evidence shows that homosexuality has been present in every culture and on every continent in recorded history (Escoffier, 2003, p. 192) ${ }^{45}$ and females make up about $49 \%$ of the world's population. It stands to reason, then, that gay women exist in every society and every culture on the planet, creating a target population that is as diverse as the entirety of humanity.

Studying all lesbians, of course, is neither possible nor necessary. My goal is simply to show that various forms of marginalization intersect to shape individual experience in unique ways. I need only show the ways in which intersectionality functions for one group of individuals, not all groups. I chose to use Black lesbians for my analysis for several reasons. First, as Lisa Bowleg noted, Black lesbians operate within several oppressed social structures—race, gender, sexual orientation — making them an excellent group for demonstrating the intersectionality of oppression. Second, I chose Black lesbians because my recognition of the privileges I receive because of my racial identity as a White woman has prompted me to desire solidary with oppressed

\footnotetext{
${ }^{45}$ Jeffrey Escoffier is a White, gay man. He is the Director of Health Media and Marketing at the NYC Department of Health and Mental Hygiene.
} 
people. Third, the choice to analyze the experiences of Black lesbians reflects my geographic location - I live in a region of the country in which racial discord has most often focused on the Black/White dichotomy. I believe that, while the particular impacts of intersectional identity would be specific to the racial identity of the lesbians studied, analyzing the experiences of any racially marginalized group of lesbians would still lead to an awareness of my Whiteness and how it has shaped my decisions about when and how to share my lesbian identity.

\section{$\underline{\text { Choosing Texts }}$}

Just as it would be impossible to study all lesbians, it would be impossible to study all the interpersonal interactions in the life of even one lesbian. This thesis, therefore, has limited the exploration to three social identities—-gender (women), race (Black), and sexual orientation (lesbians) that hold out the most likelihood of demonstrating intersectionality because they are all oppressed identities. Choosing texts for analysis that offered authentic experiences of women who are marginalized due to sex, gender, race, and sexual orientation, however, was more challenging than I anticipated. My first introduction to Black lesbian life, to intersectionality, and to the complications of both was Audre Lorde's Zami: A New Spelling of My Name, published in 1982. A prolific and talented writer, Lorde coined the term biomythography to describe the book, which she explained "has the elements of biography and history of myth. In other words, it's fiction built from many sources. This is one way of expanding our vision" (Gomez, 2000, p. 72). ${ }^{46}$ Lorde's explanation of biomythography captures

\footnotetext{
${ }^{46}$ Gomez was awarded a Master of Science (1973) in journalism from Columbia University.
} 
many of the ideals of feminist research to which I aspire so her most well-known work was an easy and obvious choice as one of the Black lesbian texts to use for my analysis.

Locating other narratives written by Black lesbians, however, was problematic. Jewelle Gomez, a lesbian and author of mixed African American and Native American ancestry, wrote that, "published Black lesbian fiction writers and poets [are] an evershrinking population" (2005, p. 289). Gomez noted that after the publication of Black lesbian novels like Zami in the 1980s, the genre seemed to fade away, so that "there is less contemporary Black lesbian fiction to discuss today that there was before the socalled gay literary boom of the early 1990s" (2005, p. 290). She noted that (as of 2005) only two of the contributors to Does Your Mama Know?, the first anthology of Black lesbian stories published in fifteen years, have been published by the mainstream press; the remaining published authors have only been represented by independent, feminist presses, making their work hard to locate (Gomez, 2005, p. 292).

As an additional source, I decided on Does Your Mama Know?, published in 1997. Chronologically, it picks up where Zami left off. More importantly, however, it offers a wide diversity of Black lesbian voices - activists and academics, American-born and immigrant women, young and old, living all over the United States. The anthology was compiled by Lisa C. Moore ${ }^{47}$ an African American lesbian and the founder and editor of RedBone Press, which was created to address a dearth of Black lesbian voices in lesbian feminist publishing. In the introduction to Does Your Mama Know?, Moore noted that “...all the voices within these pages are [B]lack. There are African Americans, biracial women, Jamaican-Canadians, Haitian-Americans, Louisiana creoles,

\footnotetext{
${ }^{47}$ Moore was awarded a BA in accounting from Louisiana State and a BA in journalism from Georgia State before going on to earn an MA in anthropology from the University of Texas at Austin.
} 
Jamericans...” (1997, p. iii). She explained that her reason for compiling the collection was her "hope that this book will get [B]lack people talking, and remembering that we are yet another layer of richness in the [B]lack community" (Moore, 1997, p. iv).

As a White woman, I am in no position to decide how effectively Black lesbian narratives reflect Black lesbian lives. I can think of no better validation of my source selections, however, than the narrators themselves. My first validation was found in the final pages of the first narrative of Does Your Mama Know? In that narrative, author Hope Massiah ${ }^{48}$ wrote:

I read Zami in one sitting, and by the end I have found a new friend and big sister. I feel Audre Lorde is saying to me: it's okay to still feel Barbadian, to be interested in politics, to struggle with ideas, to try to make sense of the world, to miss my family, to miss church, to want to live in a different way, to love women, even [W]hite women.

Zami also shows me that somewhere there is a world of Black women: frying fish, getting dressed up, having parties, falling in love. Black women with Black women, not just taking a respite from racism, but living their lives. (1997, pp. 1415)

Massiah was not the only contributor to Does Your Mama Know? for whom Zami was an important work. In an essay reflecting on the suicide of her friend, Terri Jewell (who contributed two pieces to the anthology), African American poet Valerie Jean, a selfidentified heterosexual, noted that, "we both adored Audre Lorde, quoted her to each other" (1998, p. 225). Jean's reflections were published in another anthology, one that also contained two pieces by Lorde.

Audre Lorde passed away from breast cancer in 1992, five years before Does Your Mama Know? was published, so there is little evidence to indicate her opinion of the narratives it contains. The best I could do was an implied approval. One of the

\footnotetext{
${ }^{48}$ No information on Massiah's educational background or current position could be located.
} 
sources cited in this thesis is an interview of Audre Lorde conducted by Jewelle Gomez, who is often cited alongside Lorde as one of the most influential Black lesbian writers in the $20^{\text {th }}$ century. Lorde's willingness to be interviewed by Gomez suggests that perhaps she saw Gomez as a peer.

\section{$\underline{\text { Researcher Identity }}$}

By using feminist standpoint as the framework for my analysis, I am engaging in a 'bottom up' analysis that forces me and the reader to achieve a level of understanding of those in more marginalized positions. Part of that process requires me to specifically reveal my social location. As a lesbian studying how racial identity impacts the communication of sexual orientation in lesbians, I am both a researcher and participant in the construction of knowledge. My standpoint in this process of knowledge construction is shaped by multiple social structures. I am a biologically female, cis-gendered, ${ }^{49}$ feminine performing, White lesbian. I have a full-time job, teach classes for extra income, and consider myself to be middle-class. I hold a Bachelor's degree in Liberal Studies and graduate certificates in Women's and Gender Studies and Pan African Studies from a public, research-based university in the southeastern United States. My spirituality is comprised of elements from Buddhism, Hindu, Wicca, and Pagan practices. I am a solitary practitioner, with no affiliation to any place of worship or organized religious or spiritual belief. I offer these identities to demonstrate the ways in which I am both oppressed and privileged. I maintain marginalized identities as both a woman and a lesbian, but also enjoy the racial privileges of being White, and the gendered privileges of

\footnotetext{
${ }^{49}$ Cis- is a term used to describe an individual whose internal gender identity is consistent with their biological sex.
} 
being a cis-gendered, biological woman. I have offered my middle-class status and my spiritual identity in addition to my identity in the structures of race, sex, gender, and sexual orientation so as to expose biases I may have in interpreting the interpersonal experiences of lesbians who may be situated differently in the social structures of class and religious/spiritual beliefs.

The combination of my privileged and oppressed identities has guided my research interest in the experiences and interpersonal interactions of Black lesbians. I am interested because I am concerned with my oppression but I am also concerned with the ways in which I contribute to the oppression of others. Paulo Freire noted in Pedagogy of the Oppressed that, "during the...struggle [for freedom from oppression], the oppressed, instead of striving for liberation, tend themselves to become oppressors" (1970, p. 44). I strive to be a radical liberator, one who "is not afraid to confront, to listen, to see the world unveiled [...and is] not afraid to meet the people or enter into dialogue with them" (Freire, 1970, p. 39). I seek, therefore, to dismantle my racial privilege in order to avoid becoming an oppressor.

In addition to my own social location I have, whenever possible, identified the race, sexual orientation, gender performance, and other demographic information about any researchers I have cited. I have attempted to identify the social location of cited researchers or experts in order to increase transparency in the research process, as is consistent with the arguments made by many feminist researchers. It is worth noting that some of my efforts have been assumptive (e.g. assuming the race or gender of a researcher based on a photo located on the internet) and the information is far from consistent, as the race, gender, sexual orientation, graduation dates, and other information 
about academic researchers is often unavailable. Whenever available, I have also noted the educational background and professional experience of the Black lesbians whose narratives I have excerpted; their race, sex, gender, and sexual orientation are implied by their inclusion in the source material. 


\begin{abstract}
ANALYSIS
"If I didn't define myself for myself, I would be crunched into other people's fantasies for me and eaten alive."

The texts I've selected for this thesis provide an abundance of material for analysis. There is no uniformity to the topics covered by the authors. It isn't a collection of Black lesbian stories about being ostracized by family, or excluded from communities of faith, or even being oppressed by those with privilege, but all of those topics and more are touched on. The particular topics covered in each text have been subjectively decided by the narrators and reflect the issues that were most salient to them at the time they created the text. Some of the narrators offer very narrowly focused narratives, while others place their experiences within larger social structures. I have selected a variety of excerpts that recall interpersonal interactions - with family and friends, with Whites and other Blacks, in public and in private. The excerpts I have selected all address either feelings of isolation or clashes with others stemming from the narrator's race, gender, or sexual orientation. I have then used the research of Black theorists and scholars to contextualize the excerpts. At times, numerous narrators have offered experiences that connect with the research and at other times, only one narrator's voice is used; when numerous voices are presented, they are separated by a line and an ellipsis. By connecting micro-level narratives with macro-level research on social structures, I hope to illuminate the ways in which race, gender, and sexual orientation intersect in the lives of the Black
\end{abstract}


lesbian narrators and contribute to how they choose to present themselves to the world around them, and understand their place in it.

\begin{abstract}
$* * *$
To the pale girl who ran up to my car in a Staten Island midnight with only a nightgown and bare feet, screaming and crying, "Lady, please help me oh please take me to the hospital..." [...]

And when she saw my face in the streetlamp her own collapsed in to terror.

“Oh no!” she wailed. "Not you!” [...]

What could she have seen in my Black face that was worth holding onto such horror? Wasting me in the gulf between who I was and her vision of me. (Lorde, 1982, p. 5)

Lorde recounted this interaction in a section in which she recalled the many women who helped to shape her identity as a woman. Not all of the White women Lorde encountered, however, were afraid of her Blackness, and she (and other Black lesbians) often tried to
\end{abstract} build solidarity with them:

However imperfectly, we tried to build a community of sorts where we could, at the very least, survive within a world we correctly perceived as hostile to us; we talked endlessly about how best to create that mutual support which twenty years later was being discussed in the women's movement as a brand-new concept. Lesbians were probably the only Black and [W] hite women in New York City in the fifties who were making any real attempt to communicate with each other; we learned lessons from each other, the value of which were not lessened by what we did not learn. (Lorde, 1982, p. 179)

Before an action, we stand in a circle, arms linked, drawing strength from each other. They are my sisters. For the first time since leaving church, I have a sense of belonging, of communion, the shared purpose I have been looking for.

(Massiah, 1982, p. 8)

The lessons Black and White lesbians learned from each other in the fifties, sadly, didn't have much impact on communication between the two groups in the sixties and 
beyond. The second wave of feminism, which emerged in the sixties and empowered women to begin challenging the power structure of patriarchy, was dominated by straight, White women who had only to contend with their gendered oppression, unlike Black women who were also dealing with racial oppression. African American lesbians were well aware of the racism in the feminist movement that resulted in deeper levels of oppression for them, even if their White lesbian friends weren't.

Too often [W]hite women focus only on their oppression as lesbians, ignoring the more complex oppression of non-[W] hite women who are also lesbians. We remain outsiders in these groups, without images or political voices that echo our own. We know too clearly that, as non-[W]hite lesbians in this country, we are politically and socially at the bottom of the heap. Denial of such differences robs us of true visibility. (Silvera, 1997, p. 182)

UCLA Sociology professor Mignon Moore ${ }^{51}$ explained that second wave feminism left Black women behind because the White women controlling the direction of the movement feared that issues of race and class would divert attention from "the gendered oppression they-[W]hite women —were suffering in society" (2006, p. 116).

....on the veranda...I received my first education on "Black women's strength"... European experience coined the term "feminism," but the term "Black women's strength" reaches beyond Eurocentric definitions to describe what is the cultural continuity of my own struggles. (Silvera, 1997, p. 171)

Fearing they would be labeled as "dykes," many feminists also rejected lesbians.

White lesbian feminists responded with their own separatist movement, where they focused on rejecting the limiting confines of gender performance or at least critically analyzing the choices they made in their performance. Moore (2006) explained that they often viewed the butch/femme dichotomy as a symptom of patriarchal oppression and

\footnotetext{
${ }^{50}$ Makeda Silvera was born in Jamaica but now lives in Canada, where she is a publisher focusing on the writings Black women.

${ }^{51}$ Moore is an African American lesbian. She earned both her MA (1994) and a Ph.D. (1998) in sociology from the University of Chicago.
} 
therefore rejected it, preferring a more androgynous gender expression that was free of the "taint" of masculinity. The result was that they often moved toward a broader continuum that allowed greater variations of masculinity and femininity. This movement away from a gendered binary was a complete about-face from the view that White lesbians held in the fifties.

Felicia and I [...] were both part of the "freaky" bunch of lesbians who weren't into role-playing, and who the butches and femmes, Black and [W]hite, disparaged with the term Ky-Ky, or AC/DC. Ky-Ky was the same name used for gay-girls that slept with johns for money. Prostitutes. (Lorde, 1982, p. 178)

The shift away from dichotomous gender performance experienced by White lesbians was not experienced by Black lesbians, however, because the racism nested within both the broad feminist movement and the more targeted lesbian separatist movement left them outside the sphere of feminist empowerment. Black lesbian culture today still embraces the butch/femme dichotomy; African American lesbians tend to perform either a rigid femininity or a rigid masculinity, with feminine women predominantly coupled with masculine women (Moore, 2006, pp. 114-116).

DM: I take it you like butch?

GT: Yes, I do, I really do! I don't know what it is that makes me so attracted to butch women. I just think they are so-o-o sexy!

DM: What is butch?

GT: To me, it's an attitude. It's the way they dress, they way they carry themselves, the way they walk, talk, etc. [...] I saw this one particularly cute one with a thermal shirt on, some baggy jeans and lumberjack boots! Then she wore a baseball cap occasionally! She was real cute! Ummm!

DM: What is femme?

GT: Femme is what I consider myself to be. [...] I'm real prissy. I don't leave the house without cosmetics, if I can help it. I mean, I won't even go to the mailbox without cosmetics on. (Taylor, as ctd. by Moore, 1997, p. 274)

\footnotetext{
${ }^{52}$ Gina Taylor is the pseudonym for a woman who is an exotic dancer living in New Orleans. The cited interview was conducted by Denise A. Moore, an African American poet and lesbian living in New Orleans; no other information about her was available.
} 
Throughout Zami, Lorde reported many positive relationships with White women. Even those relationships, however, were often tainted with racial assumptions that rendered her experiences invisible; she noted that her White lesbian friends would "rather die than discuss the fact that [bouncers at the gay bars would harass her at the door] because I was Black, since of course, gay people aren't racists. After all, didn't they know what it was like to be oppressed?" (Lorde, 1982, p. 180). This was true even in her intimate relationships with White women:

But the fact of our Blackness was an issue that Felicia [the only other Black woman in Lorde's social group] and I talked about only between ourselves. Even Muriel [Lorde's White lover] seemed to believe that as lesbians, we were all outsiders and all equal in our outsiderhood. "We're all n----rs ," she used to say, and I hated to hear her say it. It was wishful thinking based on little fact; the ways in which it was true languished in the shadow of those many ways in which it would always be false. (Lorde, 1982, p. 203)

In this interaction, Lorde addressed a belief held by many White gay people, that their experiences of oppression due to their sexual orientation somehow precludes the possibility that they could be racist. The White gay community has repeatedly turned a blind eye to the unique difficulties faced by LGBT people of color "struggling to manage multiple stigmatized identities" (Greene, 2000, p. 241). ${ }^{53}$ African American gay people have written for decades about racism in White gay communities, protesting the failure of White gay people to acknowledge them or their contributions while expecting them to participate in rites of passage (e.g. "coming out") ${ }^{54}$ that endanger their ability to remain

\footnotetext{
${ }^{53}$ Beverly Greene is an African American woman. She was awarded both an MA (1977) and a Ph.D. in clinical psychology from Adelphi University.

${ }^{54}$ Coming out is the process of revealing one's homosexuality to family and friends, considered to be a definitive characteristic of homosexual identity (Escoffier, 204).
} 
in the African American churches and communities that have supported them when they have faced "hostile racist attacks from society" (Griffin, 2000, p. 90). ${ }^{55}$

As if being fat, [B]lack, and a young woman alone isn't dangerous and hell enough. Now you're not shaving under your arms and you say you're a DYKE? [...] You're not some little [W] hite girl who can get away with this. They can play all they want because they don't have the struggle you have in life... (Jewell, 1997$, p. 32$)^{56}$

I wanted to tell my mother, I am a lesbian but there's this voice inside my head sayin: "ARE YOU CRAZY?"

Do you really think you can tell her? Say it out loud, to her face?

How do I do that?

How do the [W] hite girls do it? (Henry, 1997, p. 49) ${ }^{57}$

Prior to the passage of the Civil Rights Act, one might argue that White gay people were not alone in their ignorance of racism and its impact. The invisibility of LGBT people of color in gay communities, however, continued long after the passage of that landmark legislation. White gay people in the 1980s and 1990s, for example, celebrated the growing presence of positive LGBT characters on television and in the movies, but rarely commented on the lack of racial diversity within those representations (Fejes \& Petrich, 1993). ${ }^{58}$

Her world is strange, yet familiar; the world of [W]hite people in books, films and television; the world I grew up dreaming about. (Massiah, 1997, p. 6)

\footnotetext{
${ }^{55}$ Horace Griffin is a gay, African American man. An Episcopalian minister, he earned both his MA (1993) and Ph.D. (1995) in religion from Vanderbilt University.

${ }^{56}$ Terri Jewell was a radical Black feminist activist and poet from Louisville, KY; she died of a selfinflicted gunshot wound in 1995.

${ }^{57}$ Imani Henry, an actor/poet/activist, transitioned from female to male after the publication of Does Your Mama Know?; he holds an MA (1992) in theatre arts from Emerson College.

${ }^{58}$ Fred Fejes appears to be a white male; he received a Ph.D. (1982) in communication from the University of Illinois - Urbana, with a primary research interest on queer studies. Kevin Petrich appears to be a White man; he earned a Ph.D. in from Florida Atlantic University.
} 
I am intoxicated by her, but I feel uncomfortable about the fact that I am supposed to be, that the world recognizes her tall, blonde, good looks but has nothing to say about mine. (Massiah, 1997, p. 9)

Racism is evident even in the framing of the seminal moment in the Gay Rights Movement. In June of 1969, amid a national environment of radical progressive advancement toward racial equality, a group of transgendered Black and Latino drag queens in Greenwich Village stood up to police conducting a typical raid of their bar. The resulting Stonewall Riots, which lasted three days, are considered the birth of the modern Gay Rights Movement and marked an unprecedented mass exodus from the closet of shame in which many gay people lived. Although it was people of color who created the moment that launched the movement, however, they were nearly erased from it by the late 1970s when "the movement...took on an increasingly specific racial and class character - primarily [W]hite, college educated, and often middle class" (Escoffier, 2003).

I am the only Black woman at Greenham, and I grow tired of the repeated refrain, "Why don't more Black women come to Greenham?" I ask what they are doing to reach out to Black women. They look puzzled. I suggest they contact Black women's groups. They don't know of any. How about having a Black womenonly gate? They look totally confused: "But why; we are all women." Eventually I draw away; I realize that they don't want me to tell them what they could do. They want me, a Black woman, to tell them that there is some quirk in Black women that stops them/us from wanting to get involved in the Struggle. (Massiah, 1997, p. 9)

Racism in the gay community is a pervasive problem that threatens the safety of queer people of color. African Americans, like White gay people, often seek anonymity early in the process of coming out. Just like White gay people, they often leave their communities of origin in search of that anonymity. By leaving their communities of color, however, African Americans also have to leave behind any protection from racism 
the Black community offers. There is no such safety in gay communities, which are dominated by privileged Whites who have repeatedly failed to recognize the unique difficulties faced by gay and lesbian African Americans.

Coming out to anyone is frightening, but to family most of all - and family means exposing myself as a lesbian to Black people. Quick, who doesn't quake in fear at the thought of some manner of Black person's moral outrage against lesbians and homosexuals? (Allegra, 1997, p. 154)

In the years before the Stonewall Riots, White gay people had no power and no ability to offer protection to LGBT people of color, given that they had no protection themselves. The years following the Stonewall Riots, however, saw the development of gay cultural meccas that helped to insulate gay people from homophobia. White gay people moved into cities, bought up properties in economically depressed areas, renovated them, and used them to provide housing or to open businesses catering to the growing gay community (Escoffier, 2003). Within the communities, however, White gay people exhibited the same racism that could be found among White heterosexuals. As a result, LGBT people of color were unable to access the protections of gay communities because racism prevented them from earning a living or finding the housing necessary to stay (Escoffier, 2003).

There is more at risk for us than for [W] hite women. Through three hundred years of history we have carried memories and scars of racism and violence with us. (Silvera, 1997, p. 180)

The Emancipation Proclamation may have freed African Americans from slavery, but it was no magic wand; many vestiges of the institution remained, such as the effects of the sexualization of Black bodies. In the post-antebellum era, financial success for

\footnotetext{
${ }^{59}$ Other than a listing of publications, no information is available for Donna Allegra.
} 
African Americans depended on access to White wealth, which required inclusion in White communities. Lingering hypersexualized stereotypes of Blacks, and the fear they aroused in Whites, still hampered African Americans in their efforts to achieve acceptance. African American churches, which served as the "anchor of [B]lack activism in the face of the hostile conditions that [African American] communities endured" (Gadzekpo, 2001, p. 95), ${ }^{60}$ encouraged African Americans to adopt a 'politics of respectability' intended to offset the "ethnosexual mythologies held by the dominant [W]hite culture" (Greene, 2000, p. 242) and allow African Americans to appear more palatable to Whites. Any sexual behavior deemed to be deviant by the dominant culture was therefore met with disapproval in the Black church; this disapproval included homosexuality.

According to Elijah G. Ward, ${ }^{61}$ the modern Black church "foster[s] homophobia...playing an important role in its genesis, legitimization, and weekly reinforcement in Black communities" (2005, p. 494) while theologian Horace Griffin found that "there are few arenas where the dread and condemnation of homosexuality is more noticeable than in [B]lack church settings" (2006, p. 88).

...by simply loving you, I was tearing my mother's life apart. I was an embarrassment to my family and my father. By loving you I was compromising his position in the church. There were threatening to kick you out of ministerial school. (Wilkinson, 1997, p. 161) (2 $^{62}$

\footnotetext{
${ }^{60}$ Leonard Gadzekpo is a Black Ghanaian man. He earned a BA from the University of Science and Technology in Ghana and three degrees from Bowling Green State University (1990-1997)—an MA in German, an MFA in painting, and a Ph.D. in American culture studies.

${ }^{61}$ Ward is a Black man. He holds a Ph.D. in infectious diseases, epidemiology, and public health from St. Xavier University.

${ }^{62}$ Michelle Wilkinson is a museum curator; she holds a BA from Bryn Mawr and a Ph.D. from Emory University.
} 
So, this is it. I am going to tell my mother that I am a lesbian. No more excuses. Trying to pinpoint her reaction. I want to do this. This is the right thing to do. I am ready. I feel strong enough. I can accept the consequences. I can outrun her if I have to.

I can do all things through Christ that strengthens me. (Henry, 1997, 61)

I am wicked and sinful, crazy and diseased.

Isn't that right, Mama? (Henry, 1997, p. 63)

I haven't seen my family in over a year. I've tried calling, to at least hear a voice, then hang up. But their number is now changed and unlisted. I have heard my father is following through with the counseling. It was that or jail time, which wouldn't have been much. The judge [...] commented, "I have a son, you know, about her age. I just don't know what I would have done, either, if he told me he was a faggot." (Henry, 1997, p. 55)

In the decades and centuries since slavery was abolished in the United States,

African Americans, whether heterosexual or homosexual, have depended on the connection to an extended community that could be accessed through the church to provide emotional and psychological protection from the ravages of racism - "the convenantal [sic] relationship between African peoples and God has empowered them to endure the pain of injustice while not affirming it" (Gadzekpo, 2001, p. 100)—so defiance of the norms endorsed by the church was and is an unacceptable option.

When I left church, I left my community behind me. This left my college and teaching friends, who were pretty much all [W] hite. For the first time in my life I have to go out to try to meet Black people. I went to [an anti-apartheid meeting]: all [W] hite. At Brixton Black Women's Centre, I found one dispirited woman who reminisced about the good old day [of civil rights organizing...] but had nothing to tell me about events happening now for Black women. (Massiah, 1997, p. 12)

In the 1960s, the Black church was invaluable to African Americans engaged in civil rights activism, providing the movement with "an ideological framework through which passive attitudes were transformed into a collective consciousness supportive of collective action" (Gadzekpo, 2001, p. 103). Several elements of Black church services 
served as additional ways in which the Black church was invaluable to African American communities. The customs of 'call and response' and 'shouting,' as well as the lyrics of spirituals, distinguished the Black church from the White church and linked it to the lost cultures of Africa, a connection that "supported African American psychic survival under oppression" (Mitchell, 2004, p. 15-16). ${ }^{63}$

Racism is not the only element that helped to form the Black church; the Western Bible also played an important role. Numerous Black scholars have noted the existence of theological arguments to support homophobia in the Black church (Griffin, 2000; Ward, 2005), although Griffin finds it surprising that so many Black pastors endorse the use of the same Scripture to indict homosexuality that was once used to support miscegenation $(2005,91)$.

Although Christian values have dominated the world, their effect in slave colonies is particular. Our foreparents gained access to literacy through the Bible when they were being indoctrinated by missionaries. It provided powerful and ancient stories of strength, endurance and hope which reflected their own fight against oppression. This book has been so powerful that it continues to bind our lives with its racism and misogyny. Thus, the importance the Bible plays in AfroCaribbean culture must be recognised in order to understand the historical and political context for the invisibility of lesbians.

When [...] my grandmother was confronted with my love for a woman, her reaction was determined by her Christian faith... (Silvera, 1997, p. 173)

Regardless of whether the root is hypersexual stereotypes or Christian scripture, the Black church is certainly complicit in the oppression of queer people of color; by advocating a 'culture of respectability' in Black communities, the Black church has effectively oppressed homosexuals even as it serves as a source of collective racial

\footnotetext{
${ }^{63}$ Henry Mitchell is a nationally known expert on the Black Church; his racial identity is unclear but his wife, Ella, was African American. He holds numerous degrees, earned over several decades; they include a BA and an LHD (Doctor of Humane Letters) from Lincoln University, a BD/MDiv from Union Theological Seminary, an MA in linguistics from California State University Fresno, a Th.D. from the Claremont School of Theology, and an honorary doctorate in divinity from the American Baptist Seminary.
} 
empowerment for them. The significance of this oppression cannot be overlooked in the lives of Black lesbians. It is difficult to overstate the importance of the Black church in the lives of African Americans; for many, it is an essential element in the development of racial identity and pride. Gadzekpo positions the Black church as the source of the "core values of [B]lack culture"; it is "the most important [B]lack institution in the United States" (2001, p. 95-96). Ward notes that "97\% of [B]lack people in the United States claim some religious affiliation" (2005, p. 494). As the "sole surviving social institution of the African fatherland" (DuBois, 1915, p. 113), the church provides many African Americans with a connection to a cultural identity uncorrupted by the injustice of racial oppression in America.

When we do walk out of the closet (or are thrown out), the "idealogues" of the Black community say "Yes, she was a radical sistren, but I don't know what happen, she just went the wrong way." What is implicit in this is that one cannot be a lesbian and continue to do political work... (Silvera, 1997, p. 180)

GT: Well, because brothers and other sisters that aren't gay, they have a tendency to look down upon lesbians for what we are. I don't know exactly how to say this. The first thing they holler is, "Oh, that's something the [W] hite man put on 'em, or made "em do. They trying to be like them [W] hite girls," or whatever. (Taylor, ctd. by Moore, 1997, p. 276)

And when, Bible in hand, my grandmother [...] pointed out that "this was a [W] hite people ting" or "a ting only people with mixed blood was involved in" $[\ldots]$ it was strong denial of many ordinary Black working-class women she knew. (Silvera, 1997, p. 173)

Another popular argument, particularly among Black nationalists, is the belief that homosexuality is a White man's disease. Anthropological evidence, however, refutes that claim. Homosexuals have been present at every point in recorded history, in every 
culture, on every continent (Escoffier, 2003, p. 192). In fact, the first documented instance of homosexual love comes from Egypt, where Khnumhotep and Niankhknum, royal servants who lived in $2400 \mathrm{BCE}$, were found interred in a joint tomb, surrounded by artifacts of their shared life and love (Reeder, 2000, p. 193). ${ }^{64}$ The irony in claims that homosexuality was a disease brought to the continent of Africa by White Europeans is that the morals of Europe at the time were extremely homophobic. Griffin states that "European Christian missionaries and slave traders who went into African cultures were more prone to condemn homosexuality than to condone or encourage it" (2000, p. 92). He further states that, "since homosexuality is a part of human sexuality, identified in various forms on all continents [...], it becomes a racist claim to state Africans do not express themselves with same-sex love or activity like other humans" (Griffin, 2000, p. 92).

[Homosexuals] are negatively linked with the evils of [W]hite people - "a [W]hite man's sickness." Many Blacks take the position of disdaining queerness as far worse than "talking Black and sleeping [W] hite" - an attitude which reigned in the days of Black nationalism. (Allegra, 1997, p. 154)

I clearly remember how I avoided heavy Black nationalist groups because I felt I would never pass muster for being Black enough - as a lesbian, as a student at an all-[W] hite college [...].I did not want to be around nationalists because of the sexism and homophobia voiced by that movement. Recall [internationally known civil rights activist, Freedom Rider, and leader of the Student Nonviolent Coordinating Committee] Stokely Carmichael's infamous words, "The only place for women in the movement is prone."

So many sisters hear the disdainful, dismissing put-down denial that "lesbianism is a [W] hite woman's thing." These women shut themselves up, denying the everpresent lesbianism of Black women... (Allegra, 1997, p. 155)

Ward links homophobia in the Black community with hyper-masculinity, noting that "normative conceptions of masculinity in US society are inherently heterosexist and

\footnotetext{
${ }^{64}$ No information about Greg Reeder was available.
} 
homophobic" (2005, p. 495). He finds that "anxiety over racism and related blocked social opportunities" prompts young Black men to take on a 'cool pose', asserting their masculinity through "physically and sexually aggressive behaviors" that "shore up versions of hegemonic masculinity prevalent in [B]lack communities" (Ward, 2005, p. 497). As part of the Black community, Black lesbians are just as impacted by the negative repercussions of that hypermasculinity as heterosexual women are, perhaps even more so because it prevents them from even naming themselves.

My mother was a very powerful woman. This was so in a time when that wordcombination of woman and powerful was almost unexpressable in the [W] hite american [sic] common tongue, except or unless it was accompanied by some aberrant explaining adjective like blind [...] or Black. [...]

That is why to this day I believe that there have always been Black dykes around - in the sense of powerful ad women-oriented women - who would rather have died than use that name for themselves. And that includes my momma. (Lorde, 1982, p. 15)

In Jamaica, the words used to describe [women who were suspect because they wore men's clothing or were independent and lived alone] would be "Man Royal" and/or "Sodomoite." Dread words. So dead that women dare not use these words to name themselves. They were names given to women by men to describe aspects of our lives that men neither understood nor approved. (Silvera, 1997, p. 172)

Other subtle forms of [being ostracized or punished by the community] was "scorning" the women. Meaning that you didn't eat anything from them, especially a cooked meal. It was almost as if those accused of being "man royal" or "sodomite" could contaminate. (Silvera, 1997, p. 175)

I've seen how men of all stripes have always felt safe to attack lesbians. So often I witness Black women "black-maled" in to keeping quiet because we fear being accused as "bulldagger" by Black men. This name-calling from our brothers in oppression seems to me more potent against Black women than for [W] hite women, overall. (Allegra, 1997, p. 155) 
These excerpts, while certainly not exhaustive, show how the intersection of race, gender, and sexual orientation limit the options available to Black lesbians, who face racism in gay and women's communities, homophobia in Black and women's communities, and sexism in gay and Black communities.

...a big part of what is holding me back was the feeling that if I become a lesbian, I would have to live in a [W] hite world. Black women are welcome, but it was still a [W]hite world. I enjoy visiting this world, but after five years [...] I am ready to go home. Home, where I am not Black, I am Hope. I can't go back to the home that I grew up in, the world of my family and church-I don't belong there anymore. I have to find a new home. (Massiah, 1997, p. 15). 


\section{CONCLUSION}

"In our world, divide and conquer must become define and empower." - Audre Lorde

Academic research on Black lesbians, who hold positions in numerous marginalized social identity groups_-Black, gay, female_-is scant. When scholars do study Black lesbians, it is generally by using traditional research methods to isolate one of their marginalized social identities in order to arrive generate knowledge that is generalizable to larger populations. Black lesbians, however, are not Black or gay or female at any one time; they are all of those identities simultaneously. Additionally, they are the subordinate members of each of those groups. The discrimination Black lesbians experience as subordinate members of multiple marginalized social identity groups isn't merely a sum total of the discrimination from each marginalized identity; rather, the intersections of their identities create unique forms of oppression that cannot be studied in isolation from each other.

Research that attempts to isolate any of a Black lesbian's identities will result in an additive analysis, one which assumes a summative impact that recognizes the existence of social hierarchies but misses the ways in which "distinctive social power

relations mutually construct each other" (Bowleg, 2008, p. 313). To study each of a Black lesbian's identities separately leads to the creation of "intersectional invisibility", which is a general failure to recognize multiply oppressed individuals as members of identity 
groups due to their non-prototypical appearance and/or performance (PurdieVaughns and Eibach, 2008, pp. 382) ${ }^{65}$ Purdie-Vaughns and Eibach use what they call the "librarian's dilemma" to illustrate intersectional invisibility. A librarian receives one copy of a book on African American women in US history—does she file it under Women's Studies? African American Studies? History? No matter where she places the book, casual browsers in any subject she doesn't choose won't see the book, so the experiences of African American women will be lost to a whole group of potential readers (Purdie-Vaughns and Eibach, 2008, p. 384).

Scholars in the disciplines of Black Studies, Women's and Gender Studies, and Queer Studies note that in addition to employing ineffective methods for studying intersectional experiences, research often incorrectly assumes objectivity on the part of the researcher. Implicit association research supports their assertion that objectivity is a myth. All researchers have hidden biases that impact everything about their research, from the goals of the research and the development of research questions to the decisions on what data to collect and how to analyze it. The myth of objectivity perpetuates oppression because it holds the researcher as being separate from and above the subject of study. As Freire argued, maintaining a superior position prevents the privileged from contributing to the liberation of those who are oppressed:

How can I dialogue if I regard myself as a case apart from others - mere "its" in whom I cannot recognize others "Is"? How can I dialogue if I consider myself a member of the in-group [...], the owners of truth and knowledge, for whom all non-members are "these people" or the "great unwashed"? (1970, p. 88-9)

\footnotetext{
${ }^{65}$ Valerie Purdie-Vaughns is a Black woman; she earned a Ph.D. (2004) in social psychology from Stanford University, where she is currently an Associate Professor in psychology. Richard Eibach's racial identity is unclear; he holds a Ph.D. in psychology from Cornell and is currently an Associate Professor of psychology at Canada's University of Waterloo.
} 
Academic research, however, can rise to the level of authentic dialogue if those with privilege — academic researchers — acknowledge their social power and the biases that power creates. Feminist scholars argue that one way to correct for researcher biases is for researchers to identify their social location as part of any study. Being required to consider their own social location increases the likelihood that scholars will recognize their privilege and its impact on their research, and will adjust their studies and methods to control for it.

Recognizing one' own biases, however, isn't enough. An authentic dialogue that leads to liberation must also include the development of new methods of inquiry that validate the complex experiences of multiply oppressed individuals. Studying Black lesbians, for example, not just as Blacks or women or lesbians but as individuals whose complex social identities intersect to create unique forms of marginalization, can result in an authentic dialogue about the oppression they experience. One way to validate the complex experiences of Black lesbians is to accept their version of the world as accurate. Freire argued that "[t]o exist humanly is to name the world [...but] no one can say it for another, in a prescriptive act which robs others of their words" (1970, p. 88). This thesis seeks to amplify the voices of Black lesbians by using their personal narratives, their naming of their world for themselves, to illuminate their intersectionality. It may be tempting, when reading these excerpts, to believe that the experiences these women share are "mirror[s of] the multiple role stress narratives of many contemporary [women]" (Bowleg, 2008, p. 318). To arrive at an understanding of the intersectionality of their experiences, however, researchers must "broaden their analytic scope beyond collected data to become intimately acquainted, if they are not already, with the sociohistoric 
realities of historically oppressed groups" rather than viewing them through an "individualistic or idiosyncratic framework" (Bowleg, 2008, p. 318).

Developing new methods of analysis, however, does not mean that traditional analytic methods should be completely rejected. Qualitative or quantitative traditional research does carve the complex social identities of individuals into discrete and distinctly separate boxes of identity, an approach that may be essential to creating knowledge that is generalizable to larger populations but also results in a lack of understanding about the intersectionality of identity. As Linda Alcoff noted, however, there has to be a limit to how narrowly individual identity is defined; without limits, there would be a plethora of identity groups composed of a single individual from whom researchers would be unable to generate any useful knowledge for anyone but that individual (Alcoff, 1991, pp. 7-8). Such knowledge would be unlikely to prompt the adoption of policies to address their oppression; more broadly applicable knowledge is necessary. The anti-categorical approach to research requires both micro and macro level analysis, but the macro level can only be achieved with research that quantifies individual experiences in order to detect larger social patterns. Intersectional research, therefore, has to blend traditional research methods that produce generalized knowledge and innovative methods that validate the knowledge that can be extracted from individual experiences.

This thesis makes an argument for the importance of including the micro side of analysis by employing a non-normative method of inquiry that allows the Black lesbians to label their oppression in their own words. Those oppressions are then placed in a social context using quantitative research from scholars have who experienced their own forms of intersectional oppression. By juxtaposing these two sets of voices, the analysis 
develops a more accurate picture of the oppression experienced by Black lesbians. The result of my analysis may not be generalizable to a larger public, but that need not be the goal of all research. My goal is to highlight the intersectionality of oppression experienced by Black lesbians in order to contribute to the removal of their intersectional oppression and the restoration of their humanity. Freire found that, "dehumanization, although concrete historic fact, is not a given destiny by the result of an unjust order" (1970, p. 44). The women whose narratives I have analyzed-Audre Lorde, Hope Massiah, Jewelle Gomez, Makeda Silvera, Gina Taylor, Terri Jewell, Imani Henry, Donna Allegra, and Michelle Wilkinson—may be marginalized because they are Black, female, and gay, but that is not all they are; their dehumanization does not have to become their destiny. By allowing these women to define themselves, I hope to offer a method for reconceptualizing the experiences of the oppressed in a way that empowers rather than victimizes them. It is my hope that in learning to recognize and appreciate the intersectional experiences of others, and how those experiences determine social behavior and responses, we as a species can begin to see each other not as Black or female or gay but as human. Once we can see the humanity in each other, the process for reducing oppression becomes not only easier but far more essential. And reducing that oppression should be the goal of all academic research and, indeed, all human endeavors. 


\section{REFERENCES}

About Us. (n.d.). In Project Implicit. Retrieved from https://implicit.harvard.edu/implicit/ aboutus.html.

Alcoff, L. M. (1991). The problem of speaking for others. Cultural Critique, 20 (Winter), pp. 5-32.

Allegra, D. (1997). "Lavendar sheep in the fold". In L. Moore (Ed.), Does Your Mama Know?: An anthology of black lesbian coming out stories (pp. 149-160). Decatur, GA: RedBone Press.

Badgett, M., Durso, L. and Schneebaum, A. (2013) New patterns of poverty in the lesbian, gay, and bisexual community. Executive Report. Williams Institute.

Boje, D. (2001). Narrative methods for organizational and communication research. Thousand Oaks, CA: Sage Publications.

Bowleg, L. (2008). When black + lesbian + woman doesn't equal black lesbian woman: The methodological challenges of qualitative and quantitative intersectionality research. Sex Roles. 59, pp. 312-325.

Brezina, C. (2005). Sojourner Truth's “Ain't I a woman?” speech: A primary source investigation. New York, NY: Rosen Publishing Group.

Brooks, A. (2007). Feminist standpoint epistemology: Building knowledge and empowerment through women's lived experiences. In S. N. Hesse-Biber and P. L. Leavy (Eds.) Feminist research practice (pp. 53-82), Thousand Oaks, CA: Sage Publications.

Buch, E. and Staller, K. (2007). The feminist practice of ethnography. In S. N. HesseBiber and P. L. Leavy (Eds.) Feminist research practice (pp. 53-82), Thousand Oaks, CA: Sage Publications.

Clifton, D. (2013). "What's behind criticisms of those red equal signs in your facebook feed?" Huffington Post.

Collins, P. H. (2000). Black feminist thought. New York, NY: Routledge Press.

Collins, P. H. (2005). Black sexual politics: African Americans, gender, and the new racism. New York, NY: Taylor \& Francis Group. 
Crenshaw, K. (1991). Mapping the margins: Intersectionality, identity politics, and violence against women of color. Stanford Law Review, 43(6), pp. 1241-1299.

Dade, C. (2012). Blacks, gays, and the church: A complex relationship. National Public Radio. Retrieved from http://www.npr.org/2012/05/22/153282066/blacks-gaysand-the-church-a-complex-relationship.

Davis, K. (2008). "Intersectionality as buzzword: A sociology of science perspective on what makes a feminist theory successful." Feminist Theory. 9:1, pp. 67-85

DuBois, W. E. B. (1915). The Negro. New York, NY: Henry Holt and Company.

Escoffier, J. (2003). Fabulous politics: Gay, lesbian, and queer movements, 1969-1999. In The world the sixties made: Politics and culture in recent America (pp. 191218). V. Gosse and R. Moser (eds.). Philadelphia, PA: Temple University Press.

Fejes, F. and Petrich, K. (1993). "Invisibility, homophobia, and heterosexism: Lesbians, gays, and the media." Critical Studies in Media Communication. 10:4, pp. 396422.

Foucault, M. (1997). Society must be defended: Lectures at the College de France, 19751976. New York, NY: Picador Press.

Freire, P. (1970). Pedagogy of the oppressed. New York, NY: Continuum International Publishing Group.

Gadzekpo, L. (2001). "The black church, the civil rights movement, and the future." The Journal of Religious Thought. 53/54: 2/1, pp. 95-113.

Geiger, S. (2004). “What's so feminist about women's oral history?” In S. N. HesseBiber, P. Leavy, P. and M. L. Yaiser (Eds.). Feminist perspectives on social research (pp. 399-410). New York, NY: Oxford University Press.

Giddings, P. (1984). When and where I enter: The impact of black women on race and sex in America. New York: HarperCollins Books.

Giddings, P. (1992). "The last taboo.” In Morrison, T. (Ed.) Race-ing justice, engendering power (pp. 441-465). New York, NY: Pantheon.

Gomez, J. (2000). “To grandmother's house I go.” Journal of Lesbian Studies, 4:4, pp. $71-77$.

Greene, B. (2000). African American lesbian and bisexual women. Journal of Social Issues, 56, pp. 239-249.

Greenwalk, A. and Banaji, M. (2013) Blind spot: Hidden biases of good people. New York, NY: Delacorte Press. 
Griffin, H. (2000). Their own received them not: African American lesbians and gays in black churches. Theology \& Sexuality, 12, pp. 88-100.

Hall, D. (2006). Black children and the American dilemma: The invisible tears of invisible children. Boston College Third World Law Journal, 26, pp. 9-24.

Harding, S. (2013, July 19). Beyond the "secular tic" - An interview with feminist philosopher Sandra Harding. MS. Magazine weblog. Retrieved from http://msmagazine.com/blog/2013/07/19/beyond-the-secularism-tick-aninterview-with-feminist-philosopher-sandra-harding/.

Henry, I. (1997). "Bits and pieces". In L. Moore (Ed.), Does your mama know?: An anthology of black lesbian coming out stories (pp. 49-66). Decatur, GA: RedBone Press.

Hesse-Biber, S. N., Leavy, P. and Yaiser, M. L. (Eds.). (2004). Feminist perspectives on social research. New York, NY: Oxford University Press.

hooks, bell. (2004). The will to change: Men, masculinity and love. New York, NY: Atria Books.

Hull, G. and Smith, B. (1982). Introduction. In G. Hull, P. Scott, and Smith, B. (Eds.), All the women were white, all the men were black, but some of us were brave: Black women's studies (pp. xvii-xxxii). New York, NY: The Feminist Press of the City University of New York Graduate Center.

Implicit Association Test. (n.d.). In Project Implicit. Retrieved from https://implicit.harvard.edu/implicit/iatdetails.html.

Jean, V. (1998). "writing survival”. In P. Bell-Scott and J. Johnson-Bailey (Eds.). Flatfooted truths: Telling black women's lives. New York, NY: Henry Holt.

Jewell, T. (1997). “A short account of my behavior”. In L. Moore (Ed.), Does your mama know?: An anthology of black lesbian coming out stories (pp. 31-35). Decatur, GA: RedBone Press.

Kerby, S. (2013). "How pay inequality hurts women of color." Center for American Progress.

Lanehart, S. (2009). "Diversity and intersectionality". Proceedings of the Seventeenth Annual Symposium About Language and Society, Texas Linguistic Forum, 53, pp. 1-7.

Leckenby, D. and Hesse-Biber, S. (2007). "Feminist approaches to mixed-methods research". IN S. Hesse-Biber \& P. Leavy (Eds.), Feminist research practice (pp. 249-292). Thousand Oaks, CA: Sage Publications. 
Littlejohn, S. W., \& Foss, K.A. (2011). Theories of human communication. Long Grove, IL: Waveland Press, Inc.

Lorde, A. (1982). Zami: A biomythography. Freedom, CA: The Crossing Press.

Lorde, A. (1984) The transformation of silence into language and action. Sister outsider: Essays and speeches (40-44). New York, NY: Ten Speed Press.

Massiah, H. (1997). “1985: Memories of my coming out year”. In L. Moore (Ed.), Does your mama know?: An anthology of black lesbian coming out stories (pp. 1-12). Decatur, GA: RedBone Press.

McCall, L. (2001). Complex inequality: Gender, class, and race in the new economy. New York, NY: Routledge.

Mitchell, H. (2004). Black church beginnings: The long-hidden realities of the first years. Grand Rapids, MI: William B. Eerdmans Publishing Company.

Moore, D. (1997). "Waiting to exhale: Interview with Gina Taylor”. In L. Moore (Ed.), Does your mama know?: An anthology of black lesbian coming out stories (pp. 271-280). Decatur, GA: RedBone Press.

Moore, L. (Ed.) (1997). Does your mama know?: An anthology of black lesbian coming out stories. Decatur, GA: RedBone Press.

Moore, M. (2006). Lipstick or timberlands? Meanings of gender representation in black lesbian communities." Journal of Women in Culture and Society, 32(1), pp. 113139.

Naples, N. (2003). Feminism and method: Ethnography, discourse analysis, and activist research. New York NY: Routledge Press.

National Center for Education Research. (2014). "Fast facts." Retrieved from https://nces.ed.gov/fastfacts/display.asp?id=61.

Orbe, M. and Spellers, R. (2005). "From the margins to the center: Using co-cultural theory in diverse contexts". In W. Gudykunst (Ed.), Theorizing about intercultural communication (pp. 173-191). Thousand Oaks, CA: Sage Publications.

Pew Research Center. (2015). "Changing attitudes on gay marriage [Data file]." Available from http://www.pewforum.org/2015/06/08/graphics-slideshowchanging-attitudes-on-gay-marriage/.

Purdie-Vaughns, V. \& Eiback, R.P. (2008). Intersectional invisibility: The distinctive advantages and disadvantages of multiple subordinate-group identities. Sex Roles, 59, pp. 377-391. 
Reeder, G. (2000). "Same-sex desire, conjugal constructs, and the tomb of Niankhhnum and Khnumhotep". World Archeology, 32:2, pp. 193-208.

Rubin, H. and Rubin, I. (1995). Qualitative interviewing: The art of hearing data. Los Angeles, CA: Sage Publications.

Silvera, M. (1997). "Man royals and sodomites: Some thoughts on the invisibility of Afro-Caribbean lesbians". In L. Moore (Ed.), Does your mama know?: An anthology of black lesbian coming out stories (pp. 171-184). Decatur, GA: RedBone Press.

Sprague, J. (2005). Feminist methodologies for critical researchers: Bridging differences. Walnut Creek, CA: AltaMira Press.

Ward, E. G. (2005). Homophobia, hypermasculinity, and the US black church. Culture, Health, \& Sexuality, 7, pp. 493-504.

Wilkinson, M. (1997). "Letters to Carolyn”. In L. Moore (Ed.), Does your mama know?: An anthology of black lesbian coming out stories (pp. 161-164). Decatur, GA: RedBone Press.

Winker, G. and Degele, N. (2011). "Intersectionality as multi-level analysis: Dealing with social inequality." European Journal of Women's Studies, 18:1, pp. 51-66. 


\section{CURRICULUM VITA}

NAME: $\quad$ Mary Mudd

ADDRESS: Department of Communication

310 Strickler Hall

University of Louisville

Louisville, KY 40292

DOB: $\quad$ Bayshore, NY - August 17, 1965

EDUCATION B.S., Liberal Studies

\& TRAINING: University of Louisville

2006-2007

Graduate Certificate, Pan African Studies

University of Louisville

2013-2014

Graduate Certificate, Women's and Gender Studies

University of Louisville

2013-2014

AWARDS: University of Louisville, College of Arts and Sciences, Exceptional Service to Students Award, 2009

Kentucky Alliance Against Racist \& Political Repression, Annual Honoree Award, 2008

NATIONAL

MEETING

PRESENTATIONS: The Black Unicorn: Invisibility and Black Butch Lesbians in The L Word. Paper presented at the National Council of Black Studies Annual Conference, Cincinnati, $\mathrm{OH}$. 